Nat. Hazards Earth Syst. Sci. Discuss., doi:10.5194/nhess-2016-172, 2016

Manuscript under review for journal Nat. Hazards Earth Syst. Sci.

Published: 23 June 2016

(c) Author(s) 2016. CC-BY 3.0 License.

2
M. Parrot (1), V. Tramutoli (2), Tiger J.Y. Liu (3), S. Pulinets (4), D. Ouzounov (5), N. Genzano (2), M. Lisi (2), K. Hattori (6), A. Namgaladze (7)

(1) LPC2E/CNRS, France, e-mail: mparrot@cnrs-orleans.fr, (2) University of Basilicata, Italy, (3) National Central University, Taiwan, (4) Space Research Institute, Russia, (5) Chapman University, USA, (6) Graduate School of Science, Chiba University, Japan, (7) Murmansk State Technical University, Russia,

Abstract: This paper explores multi-instrument space-borne observations in order to validate physical concepts of Lithosphere-Atmosphere-lonosphere Coupling (LAIC) in relation to major seismic events. In this study we apply already validated observation to identify atmospheric and ionospheric precursors associated with some of recent most destructive earthquakes: M8.6 of March 25, 2005 and M8.5 September 15, 2007 in Sumatra, and M7.9 May 12, 2008 in Wenchuan, China. New investigations are also presented concerning these three earthquakes and for the M7.3 March 2008 in the Xinjiang-Xizang border region, China (the Yutian earthquake). It concerns the ionospheric density, the Global Ionospheric Maps (GIM) of the Total Electron Content (TEC), the Thermal Infra-Red (TIR) anomalies, and the Outgoing Longwave Radiation (OLR) data. It is shown that all these anomalies are identified as short-term precursors, which can be explained by the LAIC concept proposed by Pulinets and Ouzounov (2011).

Keywords: earthquake, satellite, precursor, ionosphere, LAIC, TEC, TIR, OLR

1. Introduction

Since old times there are many reports about earthquakes accompanied and even preceded by abnormal phenomena involving magnetism and electricity (see for example, Milne, 1890). But these observations have suffered from a lack of precise measurements and quantification. It is not the case these days because seismic areas are well equipped (particularly in China) with a lot of various experiments, which measure many different parameters. Moreover there are satellites to observe the Earth in a broad range of wavelengths from infrared to radio waves. These satellites register parameters all around the Earth and then, it is possible to compare ground-based and satellite data at the time of large events. It was shown that many parameters significantly change in the atmosphere and in the ionosphere from a few hours up to a few days before earthquakes. At the same time, models to explain this coupling between the lithosphere-atmosphere-ionosphere have been developed.

The aim of this paper is to review precursory effects before large earthquakes in order to deduce generalities to validate LAIC models (see Sect. 2). New complementary analyses have also been done. Abnormal variations of atmospheric and ionospheric parameters observed before powerful earthquakes are presented in Sect. 3 (Sumatra 2005), Sect. 4 (Sumatra 2007), Sect. 5 (Wenchuan 2008) and Sect. 6 (Yutian, 2008), whereas discussions and conclusions will be given in Sect. 7.

\section{The LAIC concept}

The different precursors that have been observed prior to earthquakes by many 
Nat. Hazards Earth Syst. Sci. Discuss., doi:10.5194/nhess-2016-172, 2016

Manuscript under review for journal Nat. Hazards Earth Syst. Sci.

Published: 23 June 2016

(c) Author(s) 2016. CC-BY 3.0 License.

experiments can be linked through various mechanisms in the atmosphere and the ionosphere. Then, the same hypotheses of generation mechanism of these precursors are valid for different perturbations. LAIC models have been widely developed in several papers (see for example, Pulinets and Ouzounov (2011), Pulinets (2012), Pulinets and Davidenko (2014), and Pulinets et al. (2015)). The starting point is of course located close to the future epicentre. It concerns the activation of the fault where the permeability changes and where aerosols and gas including radon can appear (Surkov, 2015). This leads to the ionization of air molecules. Then, many different effects can occur: growth of air temperature, formation of temperature and pressure anomalies, anomalies in Outgoing Longwave infrared Radiation (OLR), redistribution of electric charges in the Earth's atmospheric system and then in the ionosphere due to the global electric circuit (Harrison et al., 2010), and apparition of anomalous electric field. It is expected that the mechanism described in the LAIC model starts to be active when some parameters exceed a threshold value which means that the system approaches to a critical state. As a possible parameter, we consider a correction of the chemical potential of water vapor at a high level of ionization. Pulinets et al. (2006) showed that the latent heat for water molecules at phase transitions is equal to its chemical potential or to the work function when the molecule separates from water droplet. The atmospheric chemical potential correction can be expressed using the air temperature at the Earth's surface and the relative air humidity (Pulinets et al., 2015). It was possible to evaluate this parameter for some earthquakes under studies in this paper.

\section{M8.6 of March 28, 2005 Sumatra}

The 2005 Sumatra earthquake, also called the Nias Earthquake occurred at 16:09:36 UTC (23:09:36 LT) on 28 March 2005 with a magnitude of about 8.6. The hypocenter was located at $2^{\circ} 04^{\prime} 35^{\prime \prime} \mathrm{N} 97^{\circ} 00^{\prime} 58^{\prime \prime} \mathrm{E}, 30 \mathrm{~km}$ below the surface of the Indian Ocean (see Figure 1 ). This earthquake generated a small tsunami relatively to the 2004 Sumatra earthquake.

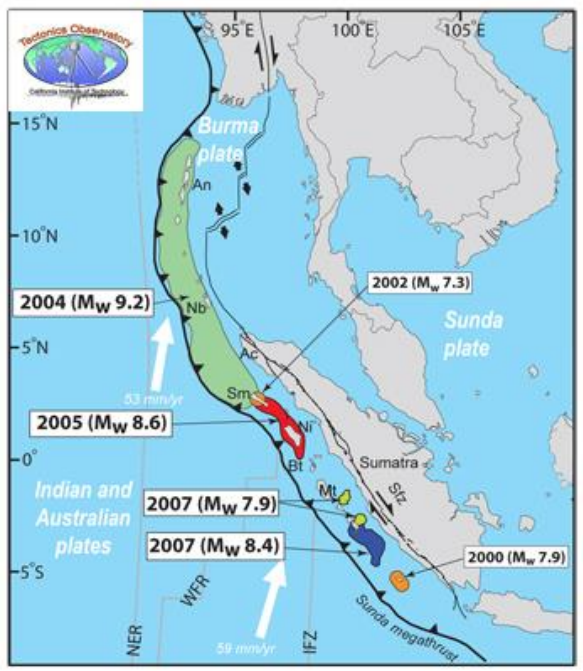

Figure 1: Map of Sumatra region showing the extent of the ruptured fault lines for the three most recent giant quakes. Green shows 2004, red shows 2005, and blue and yellow show 2007. The islands are: $\mathrm{An}=$ Andaman $\mathrm{Nb}=$ Nicobar $\mathrm{Ni}=\mathrm{Nias} \mathrm{Sm}=$ Simeulue $\mathrm{Bt}=$ Banyak $\mathrm{Mt}=$ Mentawai. Credit: Tectonic Observatory, Caltech, CA, USA (http://www.tectonics.caltech.edu/outreach/highlights/sumatra/what.html) 
Nat. Hazards Earth Syst. Sci. Discuss., doi:10.5194/nhess-2016-172, 2016

Manuscript under review for journal Nat. Hazards Earth Syst. Sci.

Published: 23 June 2016

(c) Author(s) 2016. CC-BY 3.0 License.

According to Zhang et al. (2010) the electron density showed two types of anomalies one being monotone increase in the single peak values with amplitudes exceeding $1 \sigma$ such as on March 20 and 28 2005, the other one changing the normal single peak to double crest and trough in the equatorial area which occurred on March 22 and 23, 2005.
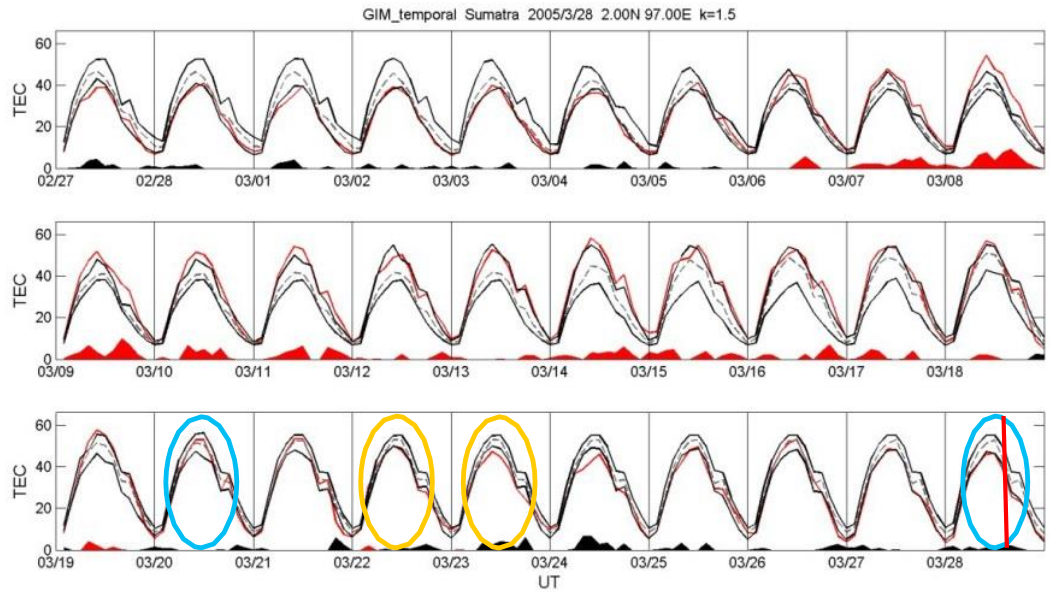

5

\section{(7)}

Figure 2: GIM TEC data recorded between February 27 and March 28, 2005. The red, blue, and two black curves denote the GIM TEC, associated median, and upper/lower bound (UB/LB), respectively. The $L B$ and $U B$ are constructed by the 1-15 previous days with moving median $(M)$, lower quartile (LQ), and upper quartile (UQ). Here, $L B=M-1.5(M-L Q)$ and $U B=M+$ 1.5(UQ - M). Red and black shaded areas denote differences of O-UB and LB-O, respectively, where $O$ is observed GPS TEC (for more details see Liu et al. (2011)). The red line indicates the time of the earthquake.

In this paper the TEC (Total Electron Content) has been investigated. The GIM (Global Ionospheric Maps) show in Figure 2 that the TEC over the epicenter significantly decreases during 22-24 March but is normal on 20 March. 
Nat. Hazards Earth Syst. Sci. Discuss., doi:10.5194/nhess-2016-172, 2016

Manuscript under review for journal Nat. Hazards Earth Syst. Sci.

Published: 23 June 2016

(c) Author(s) 2016. CC-BY 3.0 License.
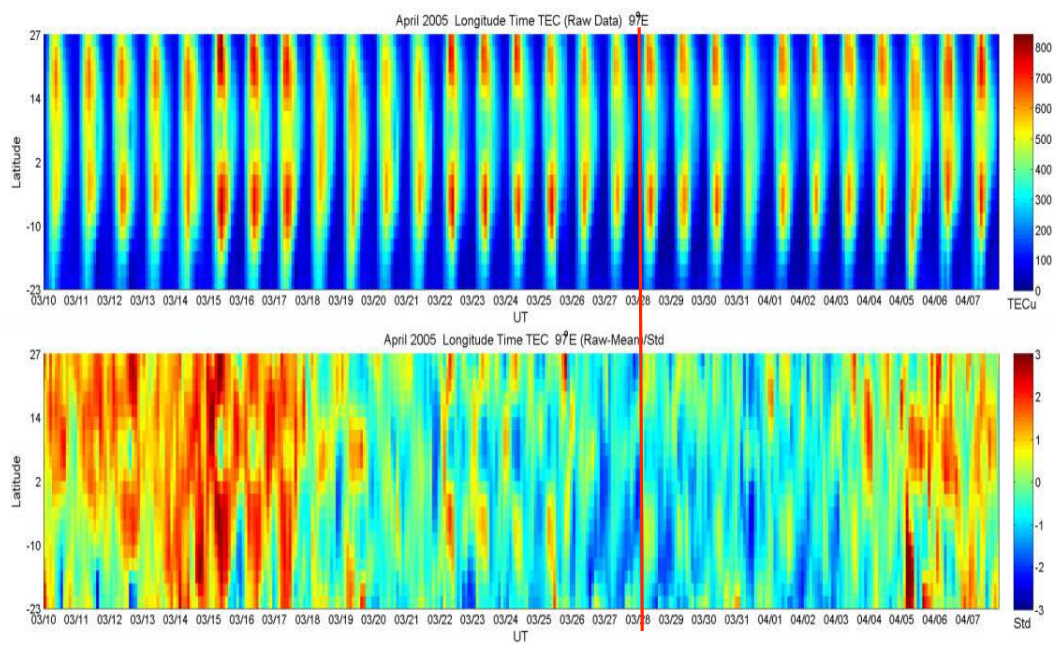

Figure 3: The top panel represents the values of the GIM TEC along the $97^{\circ} \mathrm{E}$ longitude during the time interval March $10-$ April 7, 2005 whereas the bottom panel corresponds to the relative variation. The red line indicates the time of the earthquake.

The Figure 3 shows the GIM TEC along the $97^{\circ} \mathrm{E}$ longitude during the period March $10-$ April 7 , 2005. The magnetic equator should be around $7-8^{\circ} \mathrm{N}$ latitude and therefore the EIA (Equatorial lonospheric Anomaly) crest should be $13^{\circ} \mathrm{N}$ to $18^{\circ} \mathrm{N}$ and $7^{\circ} \mathrm{S}$ to $12^{\circ} \mathrm{S}$. The top and lower panels are the GIM TEC and associated variation normalized by the standard deviation, respectively. The lower panel reveals that the northern and southern EIA crests significantly increase with $\sigma$ about 2 on March 22 and 23. It can be seen that there is no obvious feature on March 20 and 28.

Other authors have also noticed this EIA variation. Hasbi et al. (2011) have investigated the ionospheric variations using GPS (Global Positioning System) and CHAMP data. With the electron density they have shown that an equatorial anomaly modification took place a few days before the event. This modification appeared under the form of crest amplification during the daytime. Ryu et al. (2014a) studied the EIA strength with the DEMETER and CHAMP data. They have shown that the EIA was intensified along the orbits whose longitudes were close to the epicenter within about a week before and after occurrence of the earthquake during daytime.

Pulinets (2012) has noted that plasma bubbles were registered every day at night-time (22 LT) one week before the main shock, and then disappeared. He observed the formation of crests of the equatorial anomaly and two depletions equatorward from the crests at both sides from the geomagnetic equator. He noticed that at the altitude of DEMETER $(710 \mathrm{~km})$ the formation of crests was itself anomalous. Usually at these altitudes the equatorial distribution of plasma density has a single peak over the geomagnetic equator. An extremely high vertical plasma drift must be considered to explain this perturbation.

In addition to DEMETER morning passes demonstrating the formation of the equatorial anomaly before the Sumatra 2005 earthquake we analyzed the latitudinal cross-sections using the GIM maps. For the precursor's identification it is important to cross-validate the results by the different techniques of ionosphere monitoring. The only limitation is that GIM maps up to date were generated by IGS every two hours, so 10 LT is unavailable, and we used the 10.5 LT map 
Nat. Hazards Earth Syst. Sci. Discuss., doi:10.5194/nhess-2016-172, 2016

Manuscript under review for journal Nat. Hazards Earth Syst. Sci.

Published: 23 June 2016

(c) Author(s) 2016. CC-BY 3.0 License.

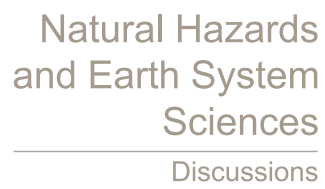

(c) (1)

1 when some intimation of the EA anomaly may appear. The latitudinal cross-sections for -4 (red) and $2-5$ (magenta) days at the epicenter longitude are presented in Figure 4 . The equatorial region 3 shape in undisturbed conditions (13 March) is shown by the green line.

4

5

6

7

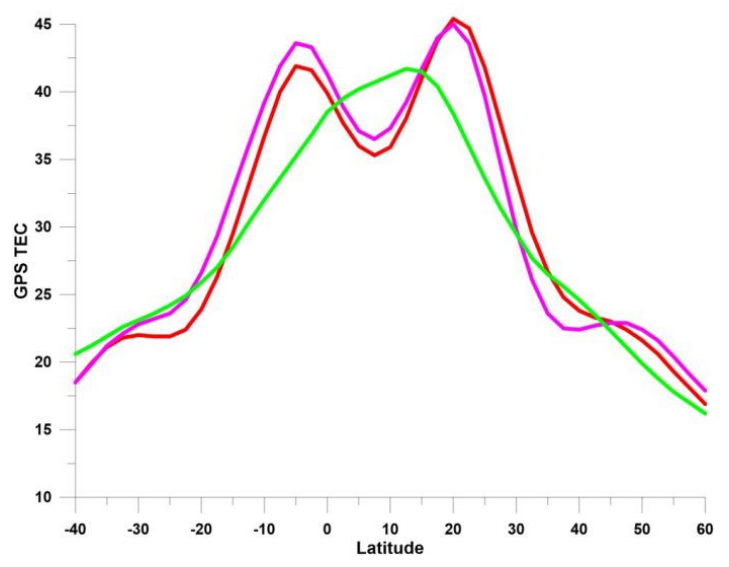

Figure 4: GPS TEC variations as function of the latitude. It shows the formation of equatorial anomaly 5 (magenta) and 4 (red) days before the Sumatra 2005 (Nias) earthquake. The shape of equatorial region in undisturbed conditions ( $13 \mathrm{March}$ ) is shown by the green line.

Determination of the location of the variations is possible by application of mapping technique. This is usually made by constructing the GIM maps for the given time period. We use the differential maps for detection. We look for anomalies appearing in the images and how close they are to the earthquake epicenter. This is demonstrated in Figure 5 which corresponds to a differential map calculated for March 23, i.e. 5 days before the earthquake. 
Nat. Hazards Earth Syst. Sci. Discuss., doi:10.5194/nhess-2016-172, 2016

Manuscript under review for journal Nat. Hazards Earth Syst. Sci.

Published: 23 June 2016

(c) Author(s) 2016. CC-BY 3.0 License.

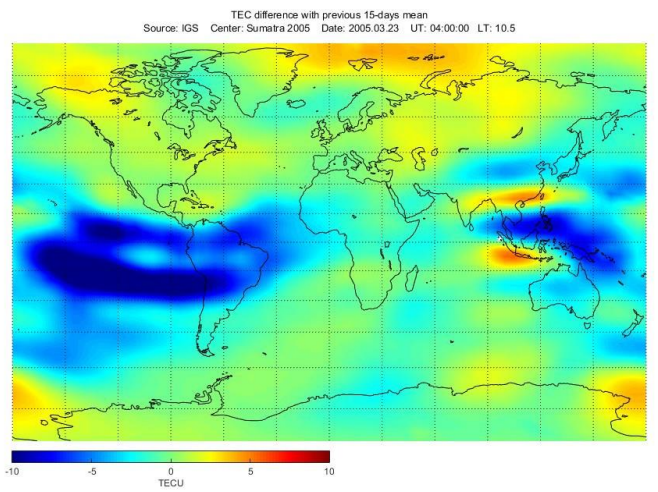

Figure 5: Differential GIM map for March 23 (5 days before the earthquake) at 10.5 LT.

3

Concerning this earthquake, particle and wave anomalies have been also detected. Six days before, bursts of precipitating electrons were detected by Zhang et al. (2013) using the DEMETER data. With the same DEMETER data, Zhang et al. (2012a) have performed a statistical analysis with 69 strong earthquakes with a magnitude above 7.0 during January 2005 to February 2010, and thus including the Sumatra earthquakes. They claimed that electrostatic perturbations in the ULF range $(<250 \mathrm{~Hz})$ are observed in the equatorial region. They have shown data recorded 20 minutes before the 28 March 2005 Sumatra earthquake at less than $2000 \mathrm{~km}$ which present this particularity together with electron density, electron temperature, and ion density variations.

\section{M8.5 September 15, 2007 in Sumatra}

The 2007 Sumatra earthquake was in fact a series of three major earthquakes. The first earthquake occurred at 11:10:26 UTC (18:10 LT) on 12 September 2007, with a magnitude of 8.5. It was located at $4.520^{\circ} \mathrm{S} 101.374^{\circ} \mathrm{E}$ with a depth of $34 \mathrm{~km}$ (see Figure 1). The second largest earthquake with a magnitude equal to 7.9 occurred later the same day at 23:49:04 UTC (06:49:04 LT the following day). It was centered at $2.506^{\circ} \mathrm{S} 100.906^{\circ} \mathrm{E}$ with a depth of 10 $\mathrm{km}$. A third earthquake with a magnitude equal to 7.0 occurred at 03:35:26 UTC (10:35:26 LT) on 13 September. It was centered at $2.160^{\circ} \mathrm{S} 99.851^{\circ} \mathrm{E}$ with a depth of $10 \mathrm{~km}$. There were many aftershocks with magnitude larger than 6 on 13, 14 and 20 September.

Hirooka et al. (2011) have established that 3 days before the earthquake at 14:00 to 15:00 LT, a strong negative TEC anomaly was detected around the earthquake epicenter. They have also investigated the three-dimensional structure of electron density in the ionosphere, using a tomographic approach. Their results have indicated a significant decrease of electron density taking place at altitudes of 250 to $400 \mathrm{~km}$, especially at an altitude of $330 \mathrm{~km}$. 
Nat. Hazards Earth Syst. Sci. Discuss., doi:10.5194/nhess-2016-172, 2016

Manuscript under review for journal Nat. Hazards Earth Syst. Sci.

Published: 23 June 2016

(c) Author(s) 2016. CC-BY 3.0 License.
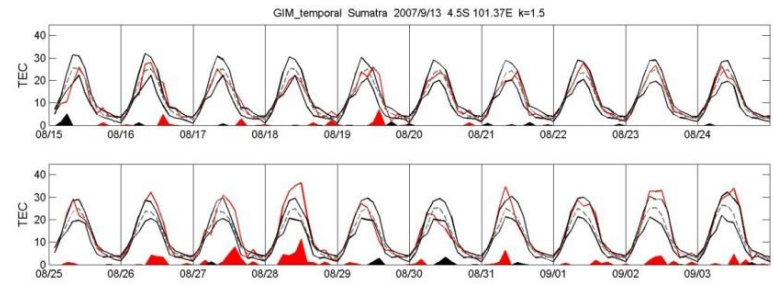

6

Figure 6: similar to Figure 2 but for GIM TEC data recorded between August 15 and September 13, 2007. The red lines indicate the time of the shock and the two main aftershocks.

As before the GIM TEC has been investigated in this study and it shows in Figure 6 that the TEC over the epicenter significantly decreases on September 9, around the noontime period, i.e., 3 days before the earthquake, which well agrees with the result reported by Hirooka et al. (2011).
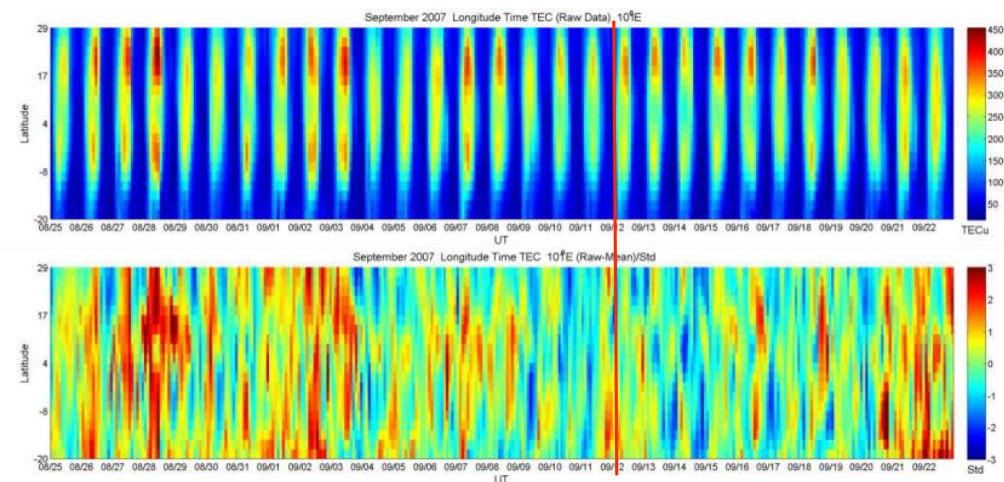

Figure 7: similar to Figure 3 but for the time interval August 25 - September 22, 2007 and along the $101^{\circ} \mathrm{E}$ longitude. The red line indicates the earthquake day.

The GIM TEC along the $101^{\circ} \mathrm{E}$ longitude has been extracted during the period August 25 - September 22, 2007. The magnetic equator should be around $7-8^{\circ} \mathrm{N}$. The top and lower panels of Figure 7 are the GIM TEC and associated variation normalized by the standard deviation, respectively. The lower panel reveals that the TEC significantly decrease with $\sigma>3$ 
Nat. Hazards Earth Syst. Sci. Discuss., doi:10.5194/nhess-2016-172, 2016

Manuscript under review for journal Nat. Hazards Earth Syst. Sci.

Published: 23 June 2016

(c) Author(s) 2016. CC-BY 3.0 License.
Natural Hazards

and Earth System

Sciences

Discussions

(c) $\underset{\mathrm{BY}}{(-)}$

1

between $5^{\circ} \mathrm{N}$ and $10^{\circ} \mathrm{S}$. Therefore the TEC significantly decrease around and south side the epicenter on September 9.

In the DEMETER data we cannot find the formation of a double hump structure at the altitude of $710 \mathrm{~km}$ because this altitude is too high, nevertheless, it is observed in GPS TEC. In Figure 8 one can observe a picture similar to Figure 4 for the same local time. As a reference we took two profiles before (3 September, green) and after (20 September, dark green) the earthquake. It is shown that the anomaly is developed 5 (7 September, magenta) and 6 (6 September, red) days before the earthquake.

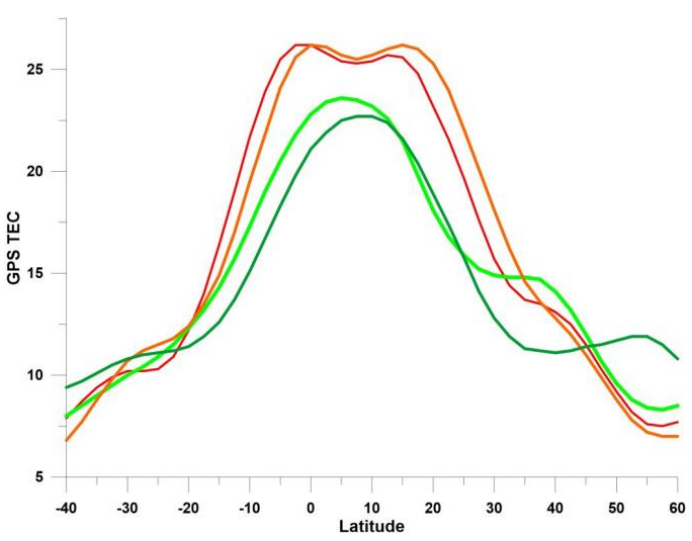

Figure 8: Formation of equatorial anomaly 5 (magenta) and 6 (red) days before the Sumatra 2007 earthquake. The shape of equatorial region in undisturbed conditions (3 September, green) and 20 September (dark green) are also shown.

In Figure 9 we also present the differential map for 07 September 2007, which shows the location of the anomaly.

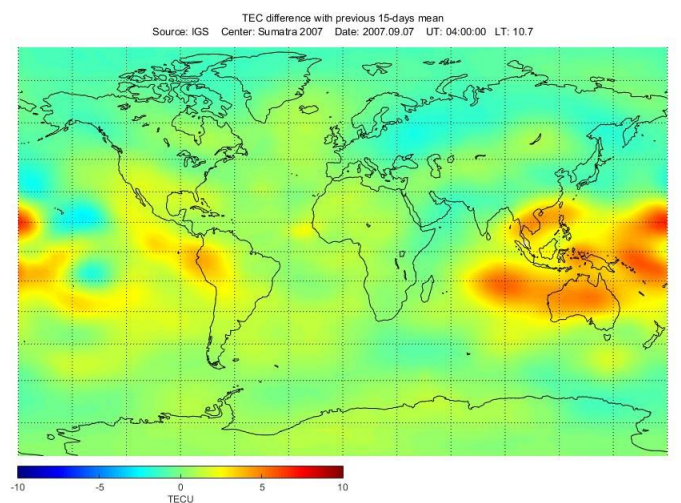

Figure 9: Differential GIM map for 07 September (5 days before the earthquake) at 10.7 LT. 
Nat. Hazards Earth Syst. Sci. Discuss., doi:10.5194/nhess-2016-172, 2016

Manuscript under review for journal Nat. Hazards Earth Syst. Sci.

Published: 23 June 2016

(c) Author(s) 2016. CC-BY 3.0 License.

Cahyadi and Heki (2013) have measured the TEC with a regional network of GPS receivers. They have determined that this earthquake, which occurred during a period of quiet geomagnetic activity, showed clear positive and negative anomalies starting 30-60 min before the earthquake to the north and the south of the fault region, respectively.

5. The Wenchuan earthquake

\section{7}

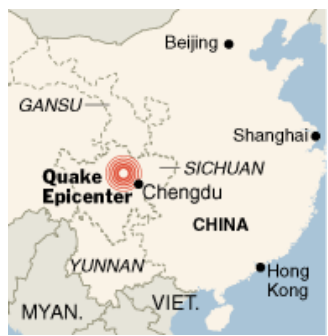

Figure 10: Map showing the location of the Wenchuan earthquake from http://www.silkroadcollection.com/sichuan-earthquake-2008.html

The Wenchuan earthquake with a magnitude of 8.0 occurred at 14:28:01 LT (06:28:01 UT) on 12 May 2008 in Sichuan province (Figure 10). The epicenter was located at $31.021^{\circ} \mathrm{N} 103.367^{\circ} \mathrm{E}$ with a focal depth of $19 \mathrm{~km}$. This devastating earthquake was the object of many studies regarding the precursors because there are a lot of experiments to record various seismic parameters in China. Singh et al. (2010) reviewed multi-satellite sensor and ground observatory data and they have reported anomalous changes in ground, meteorological and atmospheric parameters (air temperature and relative humidity) compared to other days. Electromagnetic precursors have been reviewed by Zhang and Shen (2011) and Zhang et al. (2012). They have shown that electromagnetic anomalies started 2.5 years earlier and were recorded until three days before the event. A more complete review of many different precursors has been made by $\mathrm{Ma}$ and $\mathrm{Wu}$ (2012) and their paper contains about 140 references related to various precursory phenomena observed before this earthquake. It concerns:

- Anomalies in deformation measurement which appear 3 days and 1 hour before,

- Anomalous variations in strain/stress measurements 48, 30, 8 hours and 37 minutes before,

- Possible structure variation five days before near the Longmenshan fault zone,

- Anomalous signals observed in broadband seismic and gravity records starting from about May 9 10, 2008,

- Geomagnetic anomalies 2 to 3 months before,

- Ionospheric anomalies starting from 13 to 2 days before,

- Geothermal and atmospheric anomalies, meteorological condition, temperature variation, largescale satellite Thermal Infrared Anomaly (TIR), infrared radiation anomalies, and anomalies of outgoing long-wave radiation.

In a summary diagram $\mathrm{Ma}$ and $\mathrm{Wu}(2012)$ have shown that the ionospheric anomalies are very short-term precursors with a peak appearance 5 days before the quake. The number of 
Nat. Hazards Earth Syst. Sci. Discuss., doi:10.5194/nhess-2016-172, 2016

Manuscript under review for journal Nat. Hazards Earth Syst. Sci.

Published: 23 June 2016

(c) Author(s) 2016. CC-BY 3.0 License.

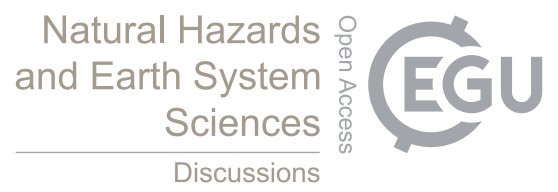

1

reports about these ionospheric anomalies is also much more important than the other precursor reports. This could be due to the many different experiments used to study the ionosphere (iono-sounder, various GPS measurements giving access to the TEC, satellites which were able to survey several ionospheric parameters). Then, the next sections will briefly detail some events observed in the ionosphere by many different experiments which underline the appearance of perturbations 5 and 3 days before the quake.

\section{1 lonospheric variations of density}

Zhao et al. (2008) have shown that the maximum ionospheric electron density in the F2 layer recorded by the Chinese iono-sounders over Wuhan $\left(30.5^{\circ} \mathrm{N}, 114.4^{\circ} \mathrm{E}\right)$ and Xiamen $\left(24.4^{\circ} \mathrm{N}\right.$, $\left.123.9^{\circ} \mathrm{E}\right)$ presented an unusual large enhancement during the afternoon-sunset sector on May 9. Using the FORMOSAT-3/COSMIC satellite constellation, Hsiao et al. (2010) were able to monitor the three-dimensional ionospheric structure with radio occultation observations. They have shown that near the epicenter the F2-peak height is about $25 \mathrm{~km}$ lower and the F2-peak electron density decreases around noon 5 days prior to the earthquake. Xu et al. (2011) observed on May 9 at 15.00-17.00 LT a variation of the F2 layer using the ionospheric sounder of the Chongqing station $\left(29.50^{\circ} \mathrm{N}, 106.40^{\circ} \mathrm{E}\right)$.

Using the LUZH GPS station $\left(28.87^{\circ}, 105.41^{\circ}\right)$ close to the epicenter, Yiyan et al. (2009) observed that VTECs were lower in the period of 07:00-09:00 UT on May 6, and larger in the periods of 04:00- 06:00 UT on May 3 and 08:00-11:00 UT on May 9, showing negative and positive anomalies, respectively. With a statistical analysis of several GPS stations close to the epicenter, Li et al. (2009) confirmed that TEC enhancements occurred on May 3 and 9. Zhao et al. (2010) also reports a change of the EIA and an anomalous enhancement in TEC $(100 \%$ increase on the 15-day median) during the afternoon-evening sector (13:00-20:00 LT, i.e. 05:00-12:00 UT) on 9 May 2008. Global lonosphere Maps (GIMs) presented by Jhuang et al. (2010) indicate that TEC anomalies occurring locally are stronger than those occurring globally at 15:00-17:00 Local Time (LT) on 29 April, 16:00 and 21:00 LT on 6 May and 14:00 and 19:00-21:00 LT on 7 May. Akhoondzadeh et al. (2010) studied TEC variations, with GIM (Global lonospheric Map) data provided by the NASA Jet Propulsion Laboratory (JPL). They have an unusual decrease of electron density $(-13 \%)$ at $\sim 22: 30$ LT, 3 days before the earthquake and an increase of the order of $39 \%$, from the normal state 9 days before the earthquake. The analysis of a dualfrequency global positioning system (GPS) receiving set-up at Guwahati $\left(26^{\circ} 10 \mathrm{~N}, 91^{\circ} 45 \mathrm{E}\right)$ made by Devi et al. (2010) with a large number of satellites indicates variations of TEC 2-3 days prior to the earthquake, i.e. on 9 and 10 May. To calculate TEC, Pulinets et al. (2010) used the global IONEX TEC maps, and the reconstructed vertical profiles of electron density according to the network of GPS receivers in the earthquake region. They have shown variations of the equatorial anomaly and they have attributed these variations to the appearance of anomalous zonal and meridional electric fields generated before this earthquake. From TEC maps, Klimenko et al. (2011) found that in the afternoon (16:00-18:00 LT) on May 9, 2008, i.e. 3 days before the earthquake, a distinct TEC enhancement appearing in the east-south direction of Wenchuan, and another enhancement in the conjugate region in the Southern Hemisphere.

Zhang et al. (2009) calculated the daily averaged values of $\mathrm{Ni}$ (ion density) recorded by the satellite DEMETER during the local nighttime from May 1 to 12 in the latitudinal interval of $20^{\circ} \mathrm{N}-40^{\circ} \mathrm{N}$ within $2000 \mathrm{~km}$ of the epicenter, and they found the lowest value three days before the Wenchuan earthquake. Zeng et al. (2009) analyzed also the DEMETER data and found that (i) electron density, electron temperature and oxygen ion density changed sharply (greater than 20\%) near the epicenter four and five days prior to the shock, (ii) Increased electromagnetic emissions were registered when the satellite passed the epicenter three and seven days before the shock (i.e. on May 5 and 9). Using the density measured by DEMETER, He et al. (2011a, b) found an anomalous increase centered close to the epicenter by comparison between values recorded just 
Nat. Hazards Earth Syst. Sci. Discuss., doi:10.5194/nhess-2016-172, 2016

Manuscript under review for journal Nat. Hazards Earth Syst. Sci.

Published: 23 June 2016

(c) Author(s) 2016. CC-BY 3.0 License.

before the quake and values recorded later on
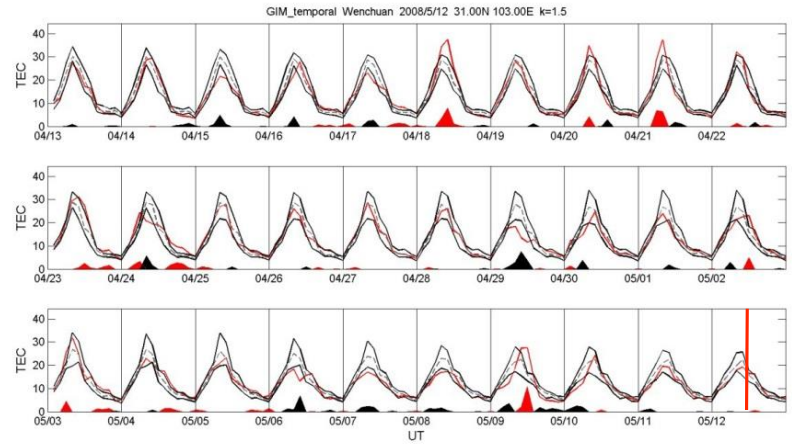

Figure 11: Similar to Figures 2 and 6 but for GIM TEC data recorded during the time interval April 13-May 12 2008. The red line indicates the earthquake day.

The GIM shows in Figure 11 that the TEC over the epicenter significantly decreases on April 29, and on May 6, i.e. 13 and 6 days before the earthquake. This well agrees with the results reported by Liu et al. (2009) and Jhuang et al. (2010). One can notice that there is a positive anomaly appearing in the afternoon of May 9. The TEC over the epicenter simply and slightly decreases during the period May $1-$ May 5.

Figure 12: Presentation of GIM TEC data similar to Figures 3 and 7 but along the $103^{\circ} \mathrm{E}$ longitude and for the time interval April 24 - May 22, 2008. The red line indicates the earthquake day.

In Figure 12, the GIM TEC along the $103^{\circ} \mathrm{E}$ longitude is extracted during the period April 24 -May 22,2008 . In this case, the magnetic equator should be around $3^{\circ} \mathrm{N}$. The top and lower panels are the GIM TEC and associated variation normalized by the standard deviation, respectively. The lower panel reveals that the TEC $20^{\circ} \mathrm{N}-40^{\circ} \mathrm{N}$ within $2000 \mathrm{~km}$ of the epicenter significantly 
Nat. Hazards Earth Syst. Sci. Discuss., doi:10.5194/nhess-2016-172, 2016

Manuscript under review for journal Nat. Hazards Earth Syst. Sci.

Published: 23 June 2016

(c) Author(s) 2016. CC-BY 3.0 License.
Natural Hazards and Earth System Sciences

Discussions (c) $($ i)

1 decreases with $\sigma>2$ during the period May 1 - May 12. This generally agrees with the DEMETER results reported by Zhang et al. (2009).
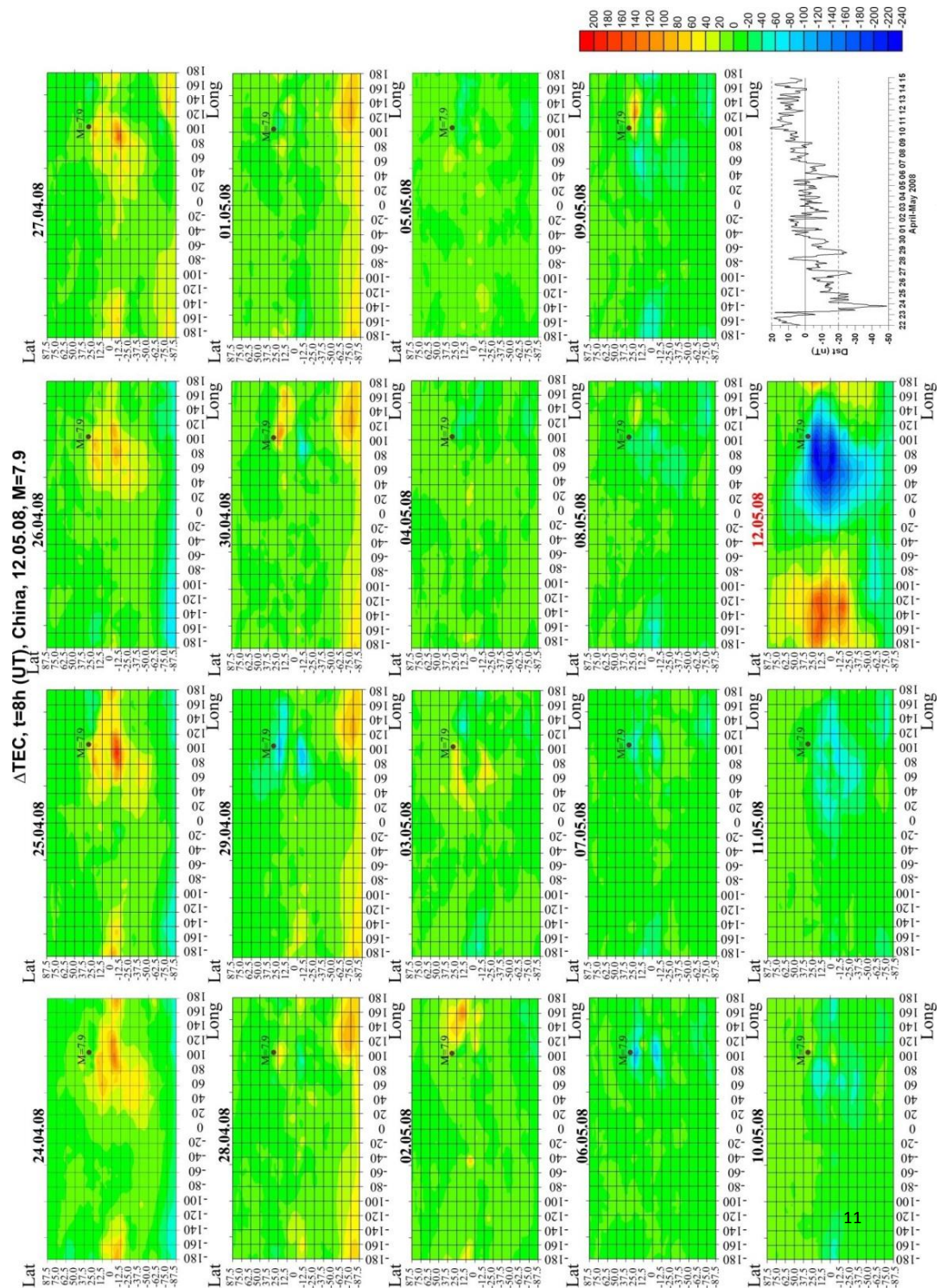

Figure 13: Differential maps of GIM TEC for the period 24 April - 12 May 2005. Each panel corresponds to data recorded during a different day at 08 UT. The right bottom panel shows the evolution of the Dst index during the same period. 
Nat. Hazards Earth Syst. Sci. Discuss., doi:10.5194/nhess-2016-172, 2016

Manuscript under review for journal Nat. Hazards Earth Syst. Sci.

Published: 23 June 2016

(c) Author(s) 2016. CC-BY 3.0 License.
Natural Hazards

and Earth System

Sciences

Discussions

A complete evolution of the position of the anomaly is shown in Figure 13 which represents the differential maps of GIM TEC. It can be seen that the anomaly is well located close to the epicenter. Except at the beginning of the investigated period one also see that the magnetic activity is quiet (right bottom panel of Figure 13) and then the observed anomalies cannot be attributed to a perturbation due to the solar activity.

The atmospheric chemical potential correction (see Sect. 2) has been evaluated for the Wenchuan earthquake. The epicenter was along the Longmenshan fault where the chemical potential correction distribution shows a minimum during all the period of the earthquake preparation. The temporal evolution of the chemical potential starting from 25 April 2008 is shown in Figure 14. In fact the main activity is observed on both sides of the Longmenshan fault (see Figure 15 where the spatial distribution of the chemical potential is shown on 01 and 11 May). So to observe this activity we have selected a point not exactly at the epicenter, but 1 degree to North and West from this epicenter, i.e. at $32^{\circ} \mathrm{N}, 102^{\circ} \mathrm{E}$.

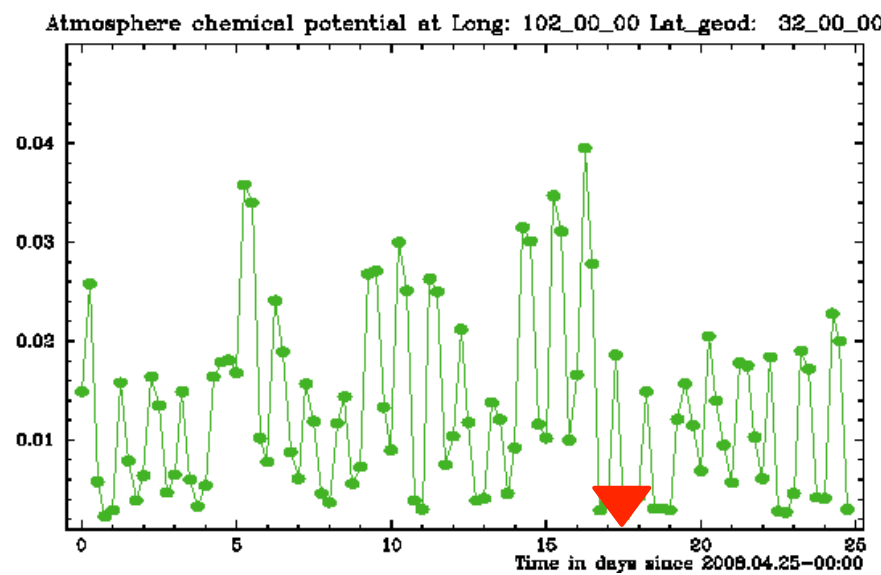

Figure 14: Atmospheric chemical potential variations for the period 25 April - 19 May 2008 at the point $32^{\circ} \mathrm{N} 102^{\circ} \mathrm{E}$. The red triangle indicates the earthquake day. 
Nat. Hazards Earth Syst. Sci. Discuss., doi:10.5194/nhess-2016-172, 2016

Manuscript under review for journal Nat. Hazards Earth Syst. Sci.

Published: 23 June 2016

(c) Author(s) 2016. CC-BY 3.0 License.

Natural Hazards

and Earth System

Sciences

Discussions

(c) $\underset{\text { BY }}{(i)}$

1

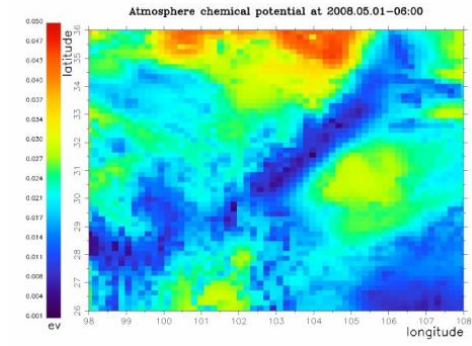

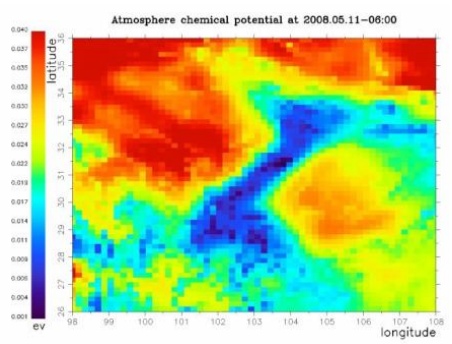

Figure 15: Chemical potential correction over of Wenchuan earthquake area on 01 May (left panel) and 11 May 2008 (right panel).

An additional analysis of the DEMETER density has been done. The DEMETER data have been checked during one month and half, one month before the shock and fifteen days after. DEMETER is only two times per day above a given region (once during daytime - 10 LT and once during night time - 22 LT). Then the data have been studied in a rectangle centred on the epicentre (longitude range between $93^{\circ}$ and $113^{\circ}$, latitude range between $22^{\circ}$ and $40^{\circ}$ ). This longitude range has been selected on order to have at least one orbit per day in the seismic region. Each orbit track is therefore more or less close to the epicentre. For each orbit, the electron density data measured by the Langmuir probe have been averaged according to the latitude. Then all daily values which are obtained at 10 LT are displayed in Figure 16. The red line represents the average value of these densities during the complete time interval and the dashed lines correspond to the variance. One can see a decrease of the density 2-3 days before the earthquake during daytime as it was reported in the ionospheric studies mentioned above. The magnetic activity is quiet during the period of Figure 16 except at the beginning in April where we see a large increase of the density witch cannot be attributed to the seismic activity. 
Nat. Hazards Earth Syst. Sci. Discuss., doi:10.5194/nhess-2016-172, 2016

Manuscript under review for journal Nat. Hazards Earth Syst. Sci.

Published: 23 June 2016

(c) Author(s) 2016. CC-BY 3.0 License.

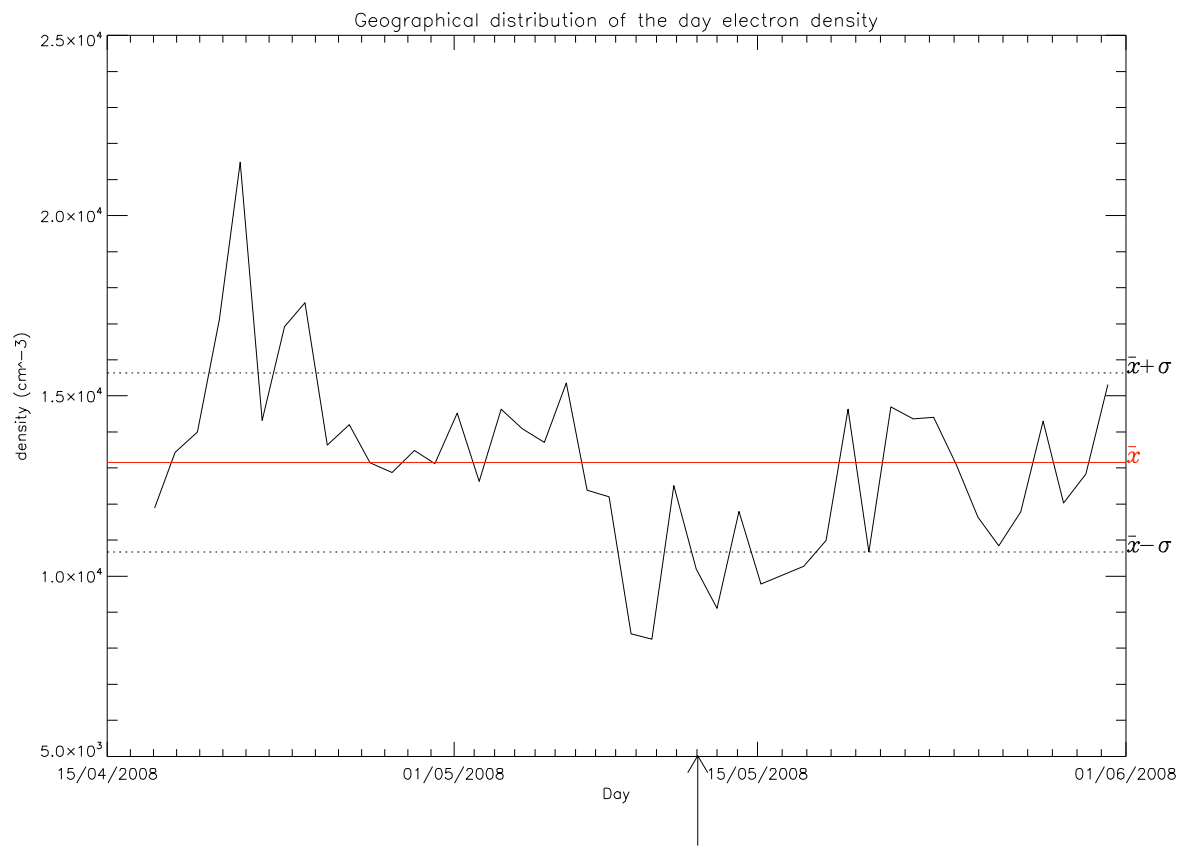

Figure 16: Day time variation of the electron density in a rectangle around the epicenter (longitude range between $93^{\circ}$ and $113^{\circ}$, latitude range between $22^{\circ}$ and $40^{\circ}$ ) as function of days. The arrow indicates the earthquake day. The red line corresponds to the average value over the considered period and the dashed lines are related to the standard deviation.

Yan et al. (2013) have compared data from GPS receivers, the DEMETER satellite, and the Advanced Very High Resolution Radiometer (AVHRR) onboard NOAA satellite. They found that GPS total electron content (TEC) above the epicenter continuously decreased in the afternoon periods from 6 to 10 May but increased in the afternoon of 9 May. The density recorded by DEMETER also decreased from 6 to 10 May, mainly in the south of the epicenter. The brightness temperature from NOAA/AVHRR data is enhanced on the northwest side of the epicenter on 7 May, while ion temperature from DEMETER data increased on 9 May. The flux of energetic particle between 100 and $600 \mathrm{keV}$ is enhanced on 6 May. They claim that the perturbations of these parameters before the Wenchuan earthquake may be related to the changes of vertical electric field in the atmosphere and ionosphere.

Using a normalized electron density of DEMETER, Ryu et al. (2014b) have shown that, during day time, there is EIA enhancements near the epicenter longitude that began approximately 1 month before the earthquake and reached its maximum with an exceptionally large strength index 8 days prior to the main shock.

\section{2 lonospheric perturbations of waves}

The analysis of the waveform of the electric field measured by DEMETER with Fourier, wavelet and bi-spectral methods has shown the presence of strong emissions in the ELF frequency range in the ionosphere 6 and 3 days before the earthquake (Blecki et al., 2010). In 
Nat. Hazards Earth Syst. Sci. Discuss., doi:10.5194/nhess-2016-172, 2016

Manuscript under review for journal Nat. Hazards Earth Syst. Sci.

Published: 23 June 2016

(c) Author(s) 2016. CC-BY 3.0 License.

the paper by Liu et al. (2011), a comparison has been made between electric field measured with ground-based stations located not far from the epicenter (less than $410 \mathrm{~km}$ ) and the ELF magnetic field recorded by DEMETER. They have shown for the first time that there is an obvious seismo-electromagnetic relation between the ground and the ionosphere because increases of the signals are observed at the same time (starting two weeks before the quake) on ground and on the satellite. Walker et al. (2013) have shown that during night the ULF noise exhibits large changes relative to the background levels at the time that DEMETER flies over the region of the epicenter, around the end of March, mid- to late-April, mid-May, and early and mid-June.

An et al. (2011) have checked the DEMETER electric field data in the ULF range and a comparison was done with data recorded by ground-based stations. They have shown an increase of the electric field amplitude (from one to two orders of magnitude) starting from April 27, 2008 to the time of the earthquake. Zhang et al. (2012b) have also studied the groundbased and satellite DC-ULF electric field data around Wenchuan. They have shown that the ground and space electric field anomalies have similar time and space behaviors. The analysis of long time series illustrates that the abnormal geoelectric field started in March 2008. Recently, Li et al. (2015) used the ULF data from two Chinese stations Chengdu and Xichang at $80 \mathrm{~km}$ and $300 \mathrm{~km}$ from the epicenter, respectively. They have found a depression of the ULF horizontal magnetic field at Chengdu a few days before the earthquake during the local night time period. They suggested that it was due to a perturbation of the lower ionosphere. The same data were differently processed by Hayakawa et al. (2015) using a natural time analysis on various ULF parameters. They have shown critical features in the time period of 17 27 April, i.e. about one month to two weeks before the earthquake.

\subsection{Outgoing Longwave Radiation (OLR) variation}

The Outgoing Longwave Radiation (OLR) from the Earth is measured at the top of the atmosphere and integrates the emissions from the ground, lower atmosphere and clouds (Ohring and Gruber, 1982). It has been primary used to study Earth radiative budget and climate (Gruber and Krueger, 1984; Mehta and Susskind, 1999).

Based on the OLR data of the geostationary satellite FY2-C and their variation characteristics, Guo et al. (2010) have proposed a method for extracting earthquake TIR, namely, the relative variance rate of power spectrum estimation. The method was applied to analyze OLR for the Wenchuan earthquake and they show perturbed maps of TIRs on May 5 and 10 .

Jing et al. (2013) have analyzed the changes in the multiple parameters of the atmosphere, including OLR, surface latent heat flux (SLHF), air temperature (AT), air relative humidity (ARH), and air pressure (AP). OLR anomalies were first observed (13 days before). Next are the abnormal variations of $A T, A R H$, and AP which occurred almost at the same time (10 days before). It is very interesting to notice that the time of anomaly occurrence of these three parameters also corresponds to the time of the increase of radon. Lastly are the SLHF abnormal variations (one day before).

Recently, Qin et al. (2014) investigated the occurrence of atmospheric aerosols with MODIS data from both Terra and Aqua satellites. They have clearly shown an enhancement of the atmospheric aerosol optical depth associated with this earthquake by using MODIS data from both Terra and Aqua. It was along the Longmenshan faults 7 days before the quake, i.e. 1 day and 4 days earlier than the reported negative and positive ionospheric disturbances, respectively. It is also interesting to note that Gu et al. (2011) found significant displacement 
Nat. Hazards Earth Syst. Sci. Discuss., doi:10.5194/nhess-2016-172, 2016

Manuscript under review for journal Nat. Hazards Earth Syst. Sci.

Published: 23 June 2016

(c) Author(s) 2016. CC-BY 3.0 License.
Natural Hazards

and Earth System

Sciences

Discussions

(c) (i)

1 anomalies concomitant with ionospheric perturbations. They have shown variations of 3 displacement components at the LUZH station $\left(28.87^{\circ}, 105.41^{\circ}\right)$ on May 9 and even a vertical displacement of more than $300 \mathrm{~mm}$ at PIXI station $\left(30.91^{\circ}, 103.76^{\circ}\right)$, i.e. at $36 \mathrm{~km}$ from the epicenter, 1 hour before the earthquake.

In this paper we study the OLR in the range of 8-12 microns. A daily mean data footprints covering a significant area $\left(90^{\circ} \mathrm{N}-90^{\circ} \mathrm{S}, 0^{\circ} \mathrm{E}\right.$ to $\left.357.5^{\circ} \mathrm{E}\right)$ with a spatial resolution of $2.5^{\circ}$ by $2.5^{\circ}$ was used to study the OLR variability in the zone of earthquake activity (Ouzounov et al., 2007, 2008; Xiong at al., 2010). An increase in radiation and a transient change in OLR were recorded at the top of the atmosphere over seismically active regions and were proposed to be related to thermodynamic processes at the Earth's surface. The OLR anomalous variations were defined by Ouzounov et al. (2007) as an E index (see Figure 17). This index is similar to the definition of an anomalous thermal field proposed by Tramutoli et al. (2005).

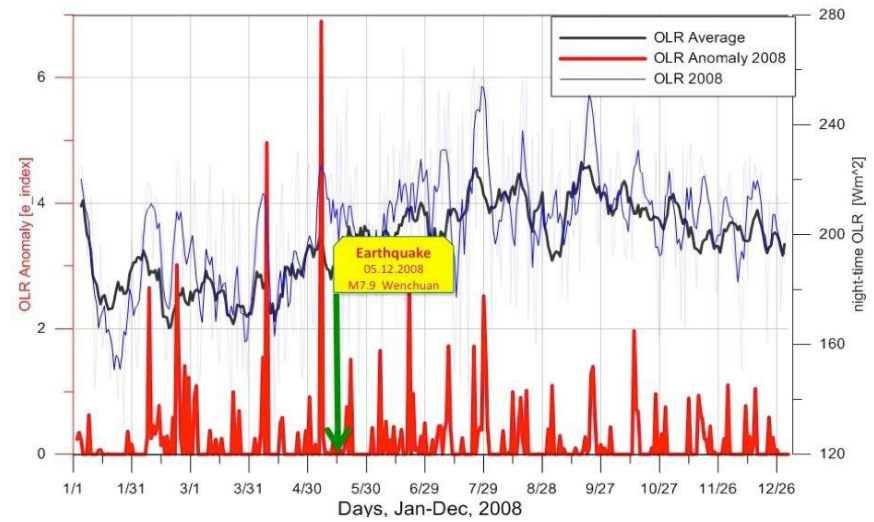

Figure 17: Time series of daily night-time NOAA/AVHRR OLR anomalous values over epicenter area in Sichuan Province for Jan-Dec 2008. OLR average values for 2008 (black), OLR daily values (blue) and anomalies for 2008 (red). The time of the M7.9 earthquake is shown with a green arrow. 
Nat. Hazards Earth Syst. Sci. Discuss., doi:10.5194/nhess-2016-172, 2016

Manuscript under review for journal Nat. Hazards Earth Syst. Sci.

Published: 23 June 2016

(c) Author(s) 2016. CC-BY 3.0 License.

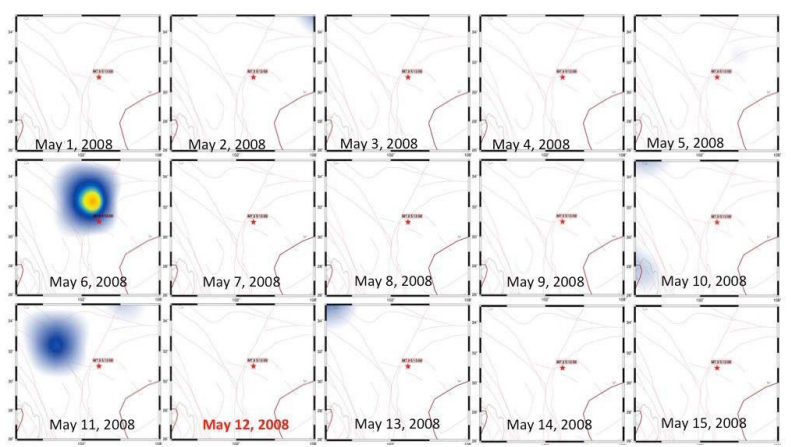

Figure 18: Daily maps for May 1-15 2008 representing the OLR anomalies spatial extent in Sichuan province epicenter area (with red star - epicenter, red solid lines- plate boundaries, brown lines - fault systems). The earthquake occurred on May $12^{\text {th }}, 2008$.

The M7.9 event of May $12^{\text {th }}$ shows OLR anomaly on May $6^{\text {th }}$ ( 6 days before the earthquake, Figures 17 and 18) that were building near to the epicenter area. The temporal variability (Fig. 18) map for the period of May 1-15, 2008 had confirmed that the maximum change in the OLR state over the epicenter area did occur on May $6^{\text {th }}$ (Ouzounov et al., 2008).

\subsection{Thermal InfraRed (TIR) anomalies}

12

Anomalies in the Earth's thermally emitted radiations, as measured by the MTSAT satellite operating in the TIR (Thermal InfraRed) spectral band, have been also observed in apparent relation with this event. The approach proposed by Tramutoli et al. $(2001,2005)$ was applied to MTSAT TIR radiances collected over the area since 2005 in order to isolate Significant Sequences of TIR Anomalies (SSTAs) from normal signal variations as well as to exclude spurious effects (see also Tramutoli et al., 2015 and reference therein). Following their definition (e.g. Elefteriou et al., 2015; Genzano et al., 2015; Tramutoli et al., 2015) an SSTA occurs when a significant TIR signal excess (> $3 \sigma$ compared with its expected value) appears persistently in space (at least $150 \mathrm{~km}^{2}$ are affected) and in time (at least one repetition in a week) domain.

Long-term correlation analyses among SSTAs and earthquakes $(M>4)$ were performed by Elefteriou et al. (2015) over Greece (10 years, 2004-2013), by Genzano et al. (2015) over Taiwan (8 years, 1995-2002), by Tramutoli et al. (2015) over Italy (1 year, 2012-2013). In those cases a positive correlation was assumed for SSTAs occurring within a space-time window of 45 days (starting 30 days before the quake ending 15 days after) and within a distance $D(150 \mathrm{~km}$ $<D<R_{D}$ where $R_{D}$ is the Dobrovolsky distance $R_{D}=10^{0.43 \mathrm{M}} \mathrm{km}$ ) from earthquakes of magnitude M. Looking to the Wenchuan area in between April 1rst, 2008 and May 31, 2008, three SSTAs were identified and their temporal relation with earthquakes with $M>5$ occurring within a distance $D$ are described in Figure 19 (one SSTA per each row) and mapped in Figure 20. It should be noted that:

- SSTAs occur all within the space-time correlation window for the Wenchuan main shock,

- SSTAs occur all before the main shock in between 1month (first appearance of SSTA 1 
Nat. Hazards Earth Syst. Sci. Discuss., doi:10.5194/nhess-2016-172, 2016

Manuscript under review for journal Nat. Hazards Earth Syst. Sci.

Published: 23 June 2016

(c) Author(s) 2016. CC-BY 3.0 License.
Natural Hazards

and Earth System

Sciences

Discussions

(c) $\underset{\mathrm{BY}}{(-)}$

and 2) and 2 weeks (last appearance of SSTA 3).

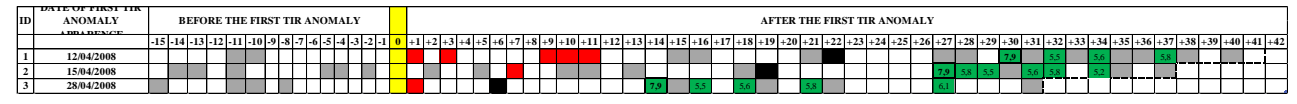

Figure 19: Correlation analysis among SSTAs and Earthquake ( $\mathrm{M}>5$ ) occurrence during the period April 1rst - May 31 2008. Each row corresponds to a succession of SSTAs occurring in a different area. Yellow cells correspond to the day (zero) of the first Significant TIR Anomalies (STA) each following persistence is depicted in red. Black and gray cells indicate, respectively, the absence of available satellite data and days with a wide cloud coverage (not usable data) in the investigated area. Green cells with numbers indicate days of occurrence, and magnitude, of seismic events. For each SSTA the end of the time-correlation window (i.e. 30 days after last STA) is bounded by dashed black line.
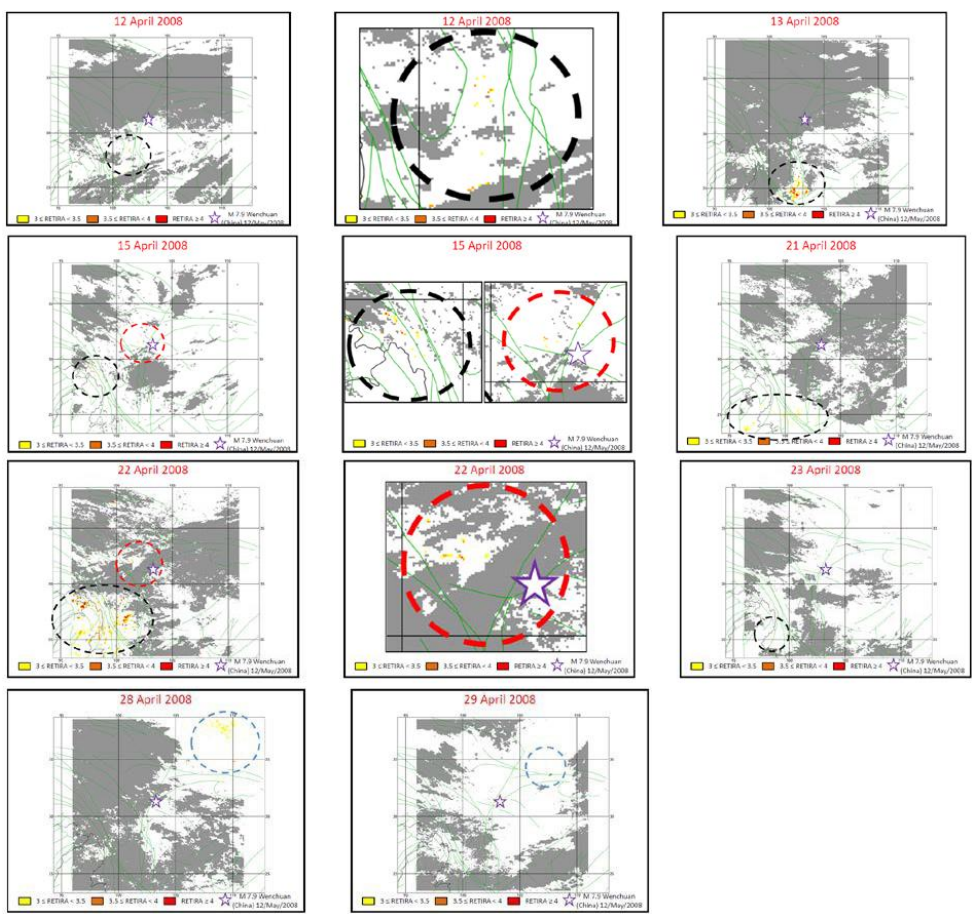

Figure 20: Space-time distribution of the 3 observed SSTAs. Significant Thermal Anomalies (STA) are differently colored depending on their relative intensities (in terms of number of $\sigma$ over the expected value, see text). Clouds (no usable data) are grey colored. Dashed circles delimit the SSTAs' affected areas: Black=SSTAs 1, Red=SSTAs 2, Blue=SSTAs 3. The star indicates the epicenter of Wenchuan EQ. Some SSTAs occurring on April 12, 15 and 22 are zoomed and reproduced close to the corresponding maps. 
Nat. Hazards Earth Syst. Sci. Discuss., doi:10.5194/nhess-2016-172, 2016

Manuscript under review for journal Nat. Hazards Earth Syst. Sci.

Published: 23 June 2016

(c) Author(s) 2016. CC-BY 3.0 License.

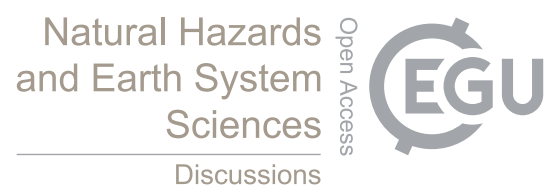

1

2

6. The M7.3 of March 21, 2008 Yutian earthquake

3

4 This M7.3 earthquake called the Yutian earthquake occurred in the Xinjiang-Xizang border region 5 on March 21, 2008 at 6.33 LT (22.33 UT). The location of the epicenter was $\left(35.6^{\circ} \mathrm{N}\right.$, $\left.6 \quad 81.6^{\circ} \mathrm{E}\right)$.

7

8

9

10

11

12

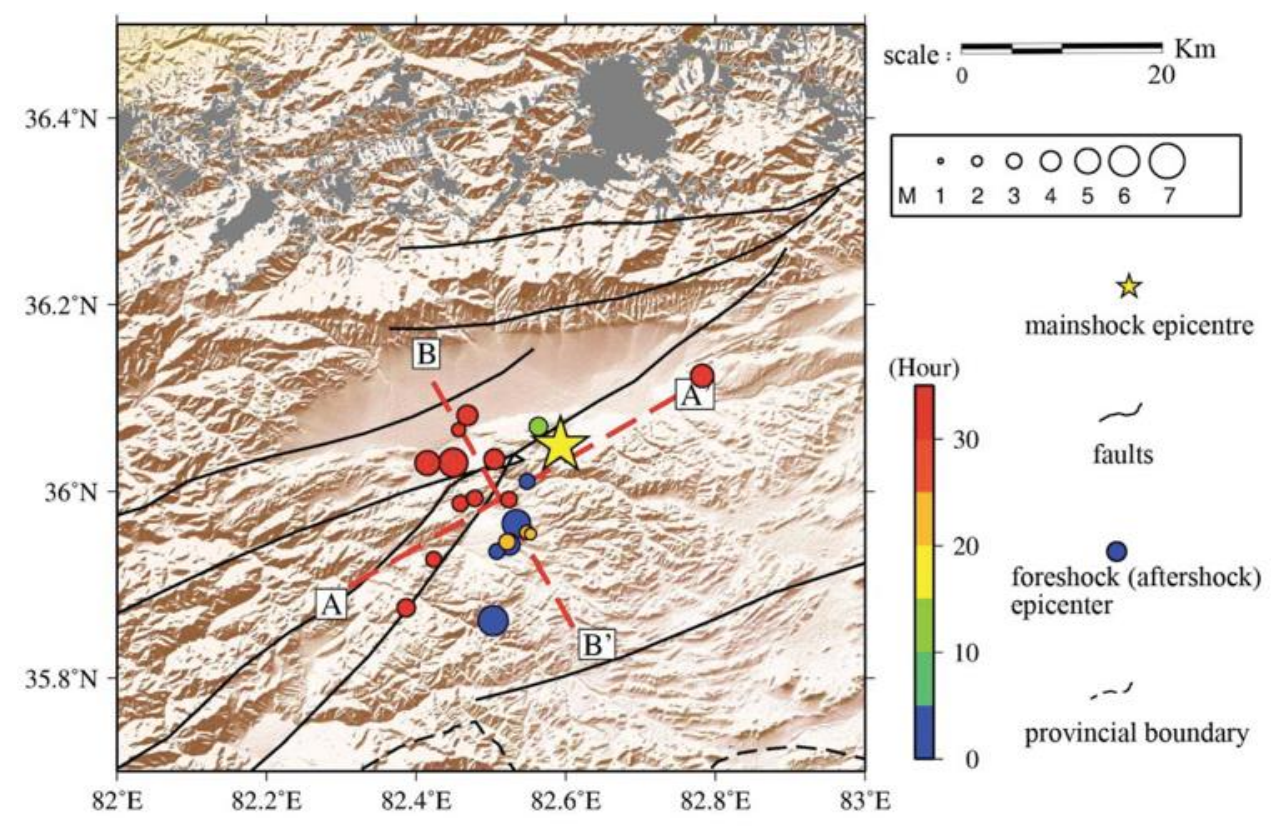

Figure 21: Map showing the location of the Yutian earthquake with the aftershocks and foreshocks. The star shows the epicenter. Source: Institute of Geophysics, CEA (2014).

2 
Nat. Hazards Earth Syst. Sci. Discuss., doi:10.5194/nhess-2016-172, 2016

Manuscript under review for journal Nat. Hazards Earth Syst. Sci.

Published: 23 June 2016

(c) Author(s) 2016. CC-BY 3.0 License.
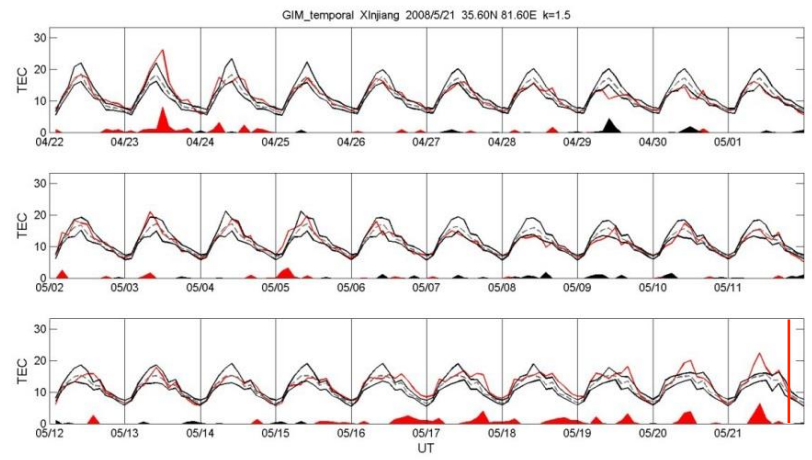

Figure 22: Similar to Figures 2, 6 and 11 but for GIM TEC data recorded during the time interval April 22- May 21 2008. The red line corresponds to the time occurrence of the earthquake.

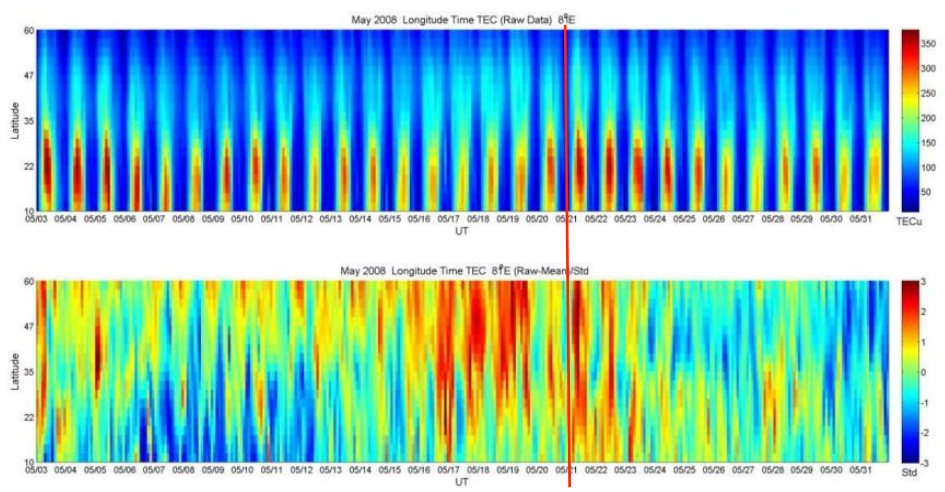

Figure 23: Presentation of GIM TEC data similar to Figures 3, 7 and 12 but along the $81^{\circ} \mathrm{E}$ longitude and for the time interval May 3 - May 31, 2008. The red line corresponds to the earthquake day.

In Figure 23, the GIM TEC along the $81^{\circ} \mathrm{E}$ longitude is extracted during the period May 331 , 2008. The magnetic equator should be around $3^{\circ} \mathrm{N}$. The top and lower panels are the GIM TEC and associated variation normalized by the standard deviation, respectively. The lower panel reveals that the TEC significantly increased with $\sigma>3$ around the epicenter during the period May 16-23. One can notice that the GIM TEC significantly increased over the epicenter on May 17.

Concerning the atmospheric chemical potential, we observe the same situation as for the Wenchuan earthquake, but the fault is different. The main activity is observed at 1 
Nat. Hazards Earth Syst. Sci. Discuss., doi:10.5194/nhess-2016-172, 2016

Manuscript under review for journal Nat. Hazards Earth Syst. Sci.

Published: 23 June 2016

(c) Author(s) 2016. CC-BY 3.0 License.

degree North from the epicenter. The time series and spatial distribution of the chemical potential 5 days before the earthquake are shown in Fig. 24.
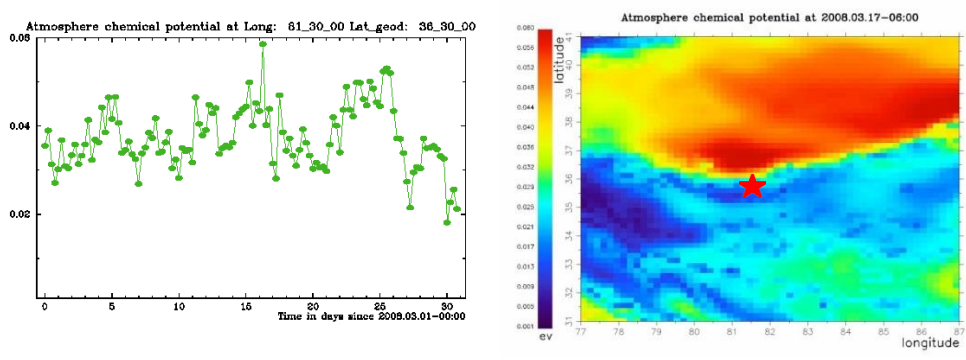

6

Figure 24: Left panel - temporal dynamics of the correction to chemical potential at the point $36.5^{\circ} \mathrm{N}, 81.5^{\circ} \mathrm{E}$; right panel - spatial distribution of the correction to chemical potential on 17 March 2008 , i.e. 5 days before the Yutian earthquake. The red star indicates the position of the epicenter.

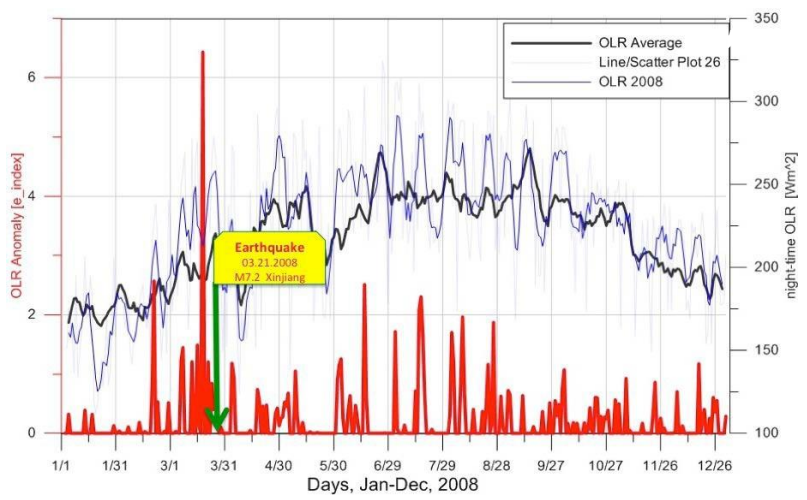

Figure 25: Time series of daily night-time NOAA/AVHRR OLR anomalous values over the M7.3 earthquake of March 21, 2008 in Xinjiang Province for Jan-Dec 2008. OLR average values for 2008 (black), OLR daily values (blue) and anomalies for 2008 (red). The time of the earthquake is shown with a green arrow. 
Nat. Hazards Earth Syst. Sci. Discuss., doi:10.5194/nhess-2016-172, 2016

Manuscript under review for journal Nat. Hazards Earth Syst. Sci.

Published: 23 June 2016

(c) Author(s) 2016. CC-BY 3.0 License.

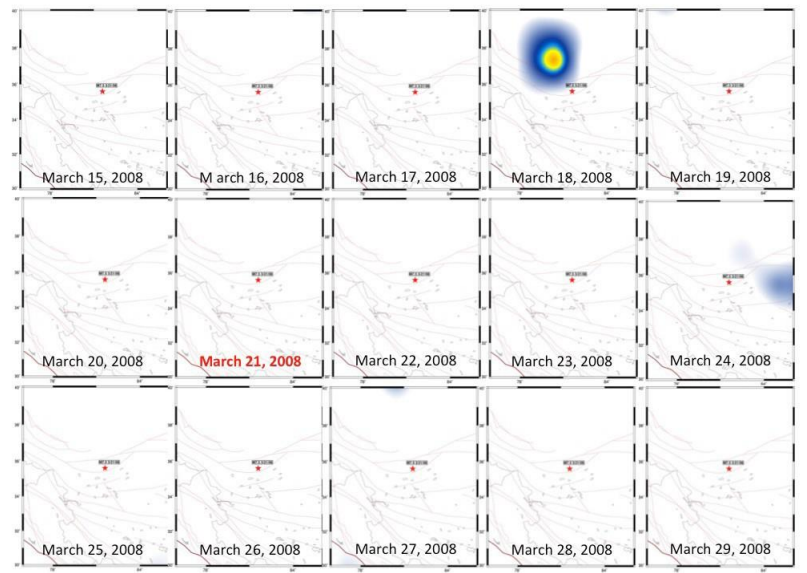

Figure 26: Daily maps for March 15-29, 2008 representing the OLR anomalies spatial extent over the M7.2 earthquake of March 21, 2008 in Xinjiang Province epicentral area (with red starepicenter, red solid lines-plate boundaries, brown lines-faultsystems).

8

In the case of this M7.2 earthquake of March 21, 2008, NOAA-15 OLR survey for January December (Figures 25 and 26) shows that the initial indication of building an atmospheric anomaly was detected in the beginning of March and the maximum was reached on March 18 west ward from the epicenter along the Altyn Tagh fault ( 3 days before the main shock). The OLR reference field was built for the entire period of 2004-2008.

\section{Discussion and conclusions}

Reviews of past studies together with new investigations of atmospheric and ionospheric parameters have been done for several powerful earthquakes. During the week preceding the earthquakes, all these parameters show clear disturbances that can be considered as short-term precursors. Two important points must be underlined: (i) these variations are expected by the proposed LAIC concept, and (ii) there is a large similarity of these variations for the different earthquakes presented in this paper. For example, our analysis of OLR from satellite during the M7.2 earthquake of March 21, 2008 in Xinjiang province and the M7.9 earthquake of May 12, 2008 in Sichuan province demonstrated the presence and reoccurrences of related variations of this parameter implying its connection with the earthquake preparation process. The same phenomena were reviled for the ionospheric perturbations of the local electron density measured from ground or by satellite, and of the global TEC measured prior to the different earthquakes. The influence of the global electric circuit between the Earth's surface and the bottom of the ionosphere has been confirmed by Fan et al. (2015) who have shown similarities between electric field simultaneously recorded 
Nat. Hazards Earth Syst. Sci. Discuss., doi:10.5194/nhess-2016-172, 2016

Manuscript under review for journal Nat. Hazards Earth Syst. Sci.

Published: 23 June 2016

(c) Author(s) 2016. CC-BY 3.0 License.

onboard DEMETER and on ground.

These results can be explained by the LAIC concept, which suggests the existence of physical links between the different atmospheric variations and tectonic activity (Ouyang et al., 2009; Pulinets and Ouzounov, 2011). The triggering process is the air ionization produced by increased emanation of radon from the Earth's crust in the vicinity of active tectonic faults (Surkov, 2015). Our findings provided evidence of the thermal build up in the form of increasing mean air temperature in the atmosphere, and change of the relative humidity because the produced ions act as the nuclei for water vapor condensation. During the condensation a large amount of latent heat is released, which leads to the air temperature changes. The measurements show that infrared temperature increases by several degrees for different large earthquakes.

Independently of the results shown here concerning the atmospheric chemical potential (Figures 14 and 24), Qin et al. (2014) have clearly shown an enhancement of the atmospheric aerosols 7 days before the Wenchuan earthquake. This is not specific of our earthquakes under studies because recently Akhoondzadeh (2015) and Ganguly (2016) have also detected variations of aerosols before the M8.8 Chile earthquake in 2010, and the M7.9 Nepal earthquake in 2015, respectively. An increased density of the charged aerosols in the warm humid air over the tectonic fault leads to the intensive vertical electric currents generation (Namgaladze and Karpov, 2015; Sorokin and Ruzhin, 2015), which results in the local disturbances of the electric field in the ionosphere and create relative TEC disturbances via the electromagnetic plasma drift (Namgaladze, 2013; Karpov et al., 2013).

Finally, the coupling interaction phenomena related to earthquakes was demonstrated in this work by the analysis of atmospheric and ionospheric observations associated with M8.6 of March 25, 2005 and M8.5 September 15, 2007 in Sumatra, M7.9 May 12, 2008 in Wenchuan, China and M7.3 March 2008 in the Xinjiang-Xizang, China earthquakes. The synergy of related variations of these parameters suggests that they follow a general temporal-spatial evolution pattern proposed by the LAIC concept, which has been seen in other large earthquakes worldwide.

\section{ACKNOWLEDGMENT}

The authors thank to the NOAA's Climate Prediction Center for OLR data. The satellite DEMETER was operated between 2004 and 2010 by the Centre National d'Etudes Spatiales. The authors thank ISSI (Beijing) for support of the team "Validation of Lithosphere-Atmosphere-lonosphereMagnetosphere Coupling (LAIMC) as a concept for geospheres interaction by utilizing space-borne multi-instrument observations".

\section{References}

Akhoondzadeh, M., Parrot, M., and Saradjian, M. R.: Electron and ion density variations before strong earthquakes $(M>6.0)$ using DEMETER and GPS data, Nat. Hazards Earth Syst. Sci., 10, 7-18, 2010.

Akhoondzadeh, M.: Ant Colony Optimization detects anomalous aerosol variations associated with the Chile earthquake of 27 February 2010, Adv. Space Res., 55, 1754-1763, 2015. 
Nat. Hazards Earth Syst. Sci. Discuss., doi:10.5194/nhess-2016-172, 2016

Manuscript under review for journal Nat. Hazards Earth Syst. Sci.

Published: 23 June 2016

(c) Author(s) 2016. CC-BY 3.0 License.

An Zhang-Hui, Du Xue-Bin, Fan Ying-Ying, Liu Jun, Tan Da-Cheng, Chen Jun-Ying, and Xie Tao: A study of the electric field before the Wenchuan 8.0 earthquake of 2008 using both space-based and ground-based observational data, Chinese J. Geophys. (in Chinese), 54(11), 2876-2884, doi: 10.3969/j.issn.0001-5733.2011.11.017, 2011.

Blecki, J., Parrot, M., and Wronowski, R.: Studies of the electromagnetic field variations in ELF frequency range registered by DEMETER over the Sichuan region prior to the 12 May 2008 earthquake, Int. J. Remote Sens., 31(13), 3615-3629, 2010.

Cahyadi, M. N., and Heki, K.: lonospheric disturbances of the 2007 Bengkulu and the 2005 Nias earthquakes, Sumatra, observed with a regional GPS network, J. Geophys. Res. Space Physics, 118, 1777-1787, doi:10.1002/jgra.5020, 2013.

Devi, M., Barbara, A.K., Depueva, A.H., Ruzhin, Y.Y. and Depuev, V.: Anomalous total electron content (TEC) and atmospheric refractivity prior to the very strong China earthquake of May 2008, Int. J. Remote Sens., 31(13), 3589-3599, 2010.

Eleftheriou, A., Filizzola, C., Genzano, N., Lacava, T., Lisi, M., Paciello, R., Pergola, N., Vallianatos, F., and Tramutoli, V.: Long-Term RST Analysis of Anomalous TIR Sequences in Relation with Earthquakes Occurred in Greece in the Period 2004-2013, Pure Appl. Geophys., 173(1), 285-303, doi: $10.1007 / \mathrm{s} 00024-015-1116-8,2016$.

Fan, Y., Du, X., An, Z., Liu, J., Tan, D., and Chen, J. : Earthquake-related Electric Field Changes Observed in the lonosphere and Ground, Acta Geophysica, 63(3), 679-697, 2015.

Ganguly, N. D.: Atmospheric changes observed during April 2015 Nepal earthquake, J. Atmos. Sol.Terr. Phy., 140, 16-22, 2016.

Genzano, N., Aliano, C., Filizzola, C., Pergola, N. and Tramutoli, V.: A robust satellite technique for monitoring seismically active areas: the case of Bhuj-Gujarat earthquake, Tectonophys., 431, 197- 210, doi: 10.1016/j.tecto.2006.04.024, 2007.

Genzano, N., Filizzola, C., Paciello, R., Pergola, N., and Tramutoli, V.: Robust Satellite Techniques (RST) for monitoring earthquake prone areas by satellite TIR observations: The case of 1999 Chi-Chi earthquake (Taiwan), J. Asian Earth Sci., 114(2), 289-298, doi:10.1016/j.jseaes.2015.02.010, 2015.

Gruber, A., and Krueger, A.F.: The Status of the NOAA Outgoing Longwave Radiation Data Set. Bull. Amer. Meteor. Soc., 65, 958-962, 1984.

Gu, G. Meng, G., and Fang, Y.: Crustal movement in the earthquake area before and after 2008 Wenchuan earthquake as detected by precise single epoch positioning of GPS observations, Acta Seismologica Sinica, 33(3), 319-326, 2011 (in Chinese).

Guo Xiao, Zhang Yuan-Sheng, Zhong Mei-Jiao, Shen Wen-Rong, and Wei Cong-Xin: Variation characteristics of ORL for the Wenchuan earthquake, Chinese J. Geophys., 53(6), 980-988, 2010.

Harrison, R.G., Aplin, K.L., and Rycroft, M.J.: Atmospheric Electricity Coupling between Earthquake 
Nat. Hazards Earth Syst. Sci. Discuss., doi:10.5194/nhess-2016-172, 2016

Manuscript under review for journal Nat. Hazards Earth Syst. Sci.

Published: 23 June 2016

(c) Author(s) 2016. CC-BY 3.0 License.

Regions and the lonosphere, J. Atmos. Sol.-Terr. Phy., 72, 376-381, 2010.

Hasbi, A.M., Mohd Ali, M.A., and Misran, N.: lonospheric variations before some large earthquakes over Sumatra, Nat. Hazards Earth Syst. Sci., 11, 597-611, 2011.

Hayakawa, M. , Schekotov, A. , Potirakis, S. , Eftaxias, K. , Li, Q. and Asano, T.: An integrated study of ULF magnetic field variations in association with the 2008 Sichuan earthquake, on the basis of statistical and critical analyses, Open Journal of Earthquake Research, 4, 85-93. doi: 10.4236/ojer.2015.43008, 2015.

He, Y., Yang, D., Qian, J., and Parrot, M.: Response of the ionospheric electron density to different types of seismic events, Nat. Hazards Earth Syst. Sci., 11, 2173-2180, doi:10.5194/nhess11-2173- 2011, 2011a.

He, Y., Yang, D., Qian, J. and Parrot, M.: Anomaly of the ionospheric electron density close to earthquakes: Case studies of Pu'er and Wenchuan earthquakes, Earthq. Sci., 24: 549-555, 2011b.

Hirooka, S., Hattori, K., Nishihashi, M., and Takeda, T.: Neural network based tomographic approach to detect earthquake-related ionospheric anomalies, Nat. Hazards Earth Syst. Sci., 11, 2341-2353, 2011.

Hsiao, C.-C., Liu, J.Y., Oyama, K.-I., Yen, N.L., Liou, Y.A., Chen, S.S., and Miau, J.J.: Seismo-ionospheric precursor of the 2008 Mw7.9 Wenchuan earthquake observed by FORMOSAT-3/COSMIC, GPS Solut, 14, 83-89, doi:10.1007/s10291-009-0129-0, 2010.

Jhuang, H.K., Ho, Y.Y., Kakinami, Y., Liu, J.Y., Oyama, K.I., Parrot, M., Hattori, K., Nishihashi, M., and Zhang, D.: Seismo-ionospheric anomalies of the GPS-TEC appear before the 12 May 2008 magnitude 8.0 Wenchuan Earthquake, Int. J. Remote Sens., 31(13), 3579-3587,2010.

Jing, F., Shen, X.H., Kang, C.L., and Xiong, P.: Variations of multi-parameter observations in atmosphere related to earthquake, Nat. Hazards Earth Syst. Sci., 13, 27-33, 2013.

Karpov, M. I., Namgaladze, A. A., and Zolotov, O. V.: Modeling of Total Electron Content Disturbances Caused by Electric Currents between the Earth and the Ionosphere, Russian Journal of Physical Chemistry B, 7(5), 594-598, doi:10.1134/S1990793113050187, 2013.

Klimenko, M.V., Klimenko, V.V., Zakharenkova, I.E., Pulinets, S.A., Zhao, B., and Tsidilina, M.N.: Formation mechanism of great positive TEC disturbances prior to Wenchuan earthquake on May 12, 2008, Adv. Space Res., 48, 488-499, 2011.

Li, Q., Schekotov, A., Asano, T. and Hayakawa, M.: On the anomalies in ULF magnetic field variations prior to the 2008 Sichuan earthquake, Open Journal of Earthquake Research, 4, 55-64, 2015.

Li, J., Meng, G., Wang, M., Liao, H. and Shen, X.: Investigation of ionospheric TEC changes related to the 2008 Wenchuan earthquake based on statistic analysis and signal detection, Earthq. Sci., 22, 545-553, 2009. 
Nat. Hazards Earth Syst. Sci. Discuss., doi:10.5194/nhess-2016-172, 2016

Manuscript under review for journal Nat. Hazards Earth Syst. Sci.

Published: 23 June 2016

(c) Author(s) 2016. CC-BY 3.0 License.

Liu, J. Y., Chen, Y. I., Chen, C. H., Liu, C. Y., Chen, C. Y., Nishihashi, M., Li, J.Z., Xia, Y.Q., Oyama, K.I., Hattori, K., and Lin, C. H.: Seismoionospheric GPS total electron content anomalies observed before the 12 May 2008 Mw7. 9 Wenchuan earthquake, J. Geophys. Res. Space Physics, 114, A04320, doi:10.1029/2008JA013698, 2009.

Liu J., Du, X.B., Zlotnicki, J., Fan Y.-Y., An, Z.H., Xie, T., Zheng, G.L., Tan, D.C., Chen, J.Y.: Changes of the electric and magnetic fields on the ground and in the ionosphere before and after several great earthquakes, Chinese J. Geophys., 54(6), 828-843, 2011.

Liu, J. Y., Le, H., Chen, Y. I., Chen, C. H., Liu, L., Wan, W., Su, Y.Z., Sun, Y.Y., Lin, C.H., and Chen, M. Q.: Observations and simulations of seismo-ionospheric GPS total electron content anomalies before the 12 January 2010 M7 Haiti earthquake, J. Geophys. Res. Space Physics, 116, A04302, doi:10.1029/2010JA015704, 2011.

Ma, T. and Wu, Z.: Precursor-like anomalies prior to the 2008 Wenchuan earthquake: a criticalbut- constructive review, International Journal of Geophysics, Volume 2012, Article ID 583097, 13 pages, doi:10.1155/2012/583097, 2012.

Mehta, A., and Susskind, J.: Outgoing longwave radiation from the TOVS pathfinder Path A data set, J. Geophys. Res., 104, 12193-12212, 1999.

Milne, J.: Earthquakes in connection with electric and magnetic phenomena, Trans. of the Seismological Society of Japan, 15, 135-162, 1890.

Namgaladze, A.A.: Earthquakes and Global Electrical Circuit, Russian Journal of Physical Chemistry B, 7(5), 589-593, doi:10.1134/S1990793113050229, 2013.

Namgaladze, A. A., and Karpov, M. I.: Conductivity and external electric currents in the global electric circuit, Russian Journal of Physical Chemistry B, 9(4), 754-757, doi:10.1134/S1990793115050231, 2015.

Ohring, G. and Gruber, A.: Satellite radiation observations and climate theory, Adv. Geophys., 25, 237-304, 1982.

Ouyang, Z., Zhang, H., Fu, Z., Gou, B., and Jiang, W.: Abnormal phenomena recorded by several earthquake precursor observation instruments before the Ms 8.0 Wenchuan, Sichuan earthquake, Acta Geologica Sinica (English Edition), 83(4), 834-844, 2009.

Ouzounov D., Liu, D., Kang,C. , Cervone, G., Kafatos, M., and Taylor, P.: Outgoing Long Wave Radiation Variability from IR Satellite Data Prior to Major Earthquakes, Tectonophysics, 431, 211- 220, 2007.

Ouzounov D., Habib, S., and Ambrose, S.: Multisensor approach analyzing atmospheric signals for possible earthquake precursors. Application of Remote Sensing for Risk Management, In the book "Risk Wise", International Disaster and Risk Conference (IDRC) Davos, Switzerland, Tudor Rose, 162- 165, 2008.

Ouzounov D., Pulinets, S., Romanov, A., Romanov Jr., A., Tsybulya, K., Davydenko, D., Kafatos, M., and Taylor, P.: Atmosphere-ionosphere response to the M9 Tohoku earthquake revealed by 
Nat. Hazards Earth Syst. Sci. Discuss., doi:10.5194/nhess-2016-172, 2016

Manuscript under review for journal Nat. Hazards Earth Syst. Sci.

Published: 23 June 2016

(c) Author(s) 2016. CC-BY 3.0 License.

joined satellite and ground observations, Earthq. Sci., 24, 557-564, 2011.

Pulinets, S.A., Ouzounov, D., Karelin, A.V., Boyarchuk, K.A., and Pokhmelnykh, L.A.: The physical nature of the thermal anomalies observed before strong earthquakes, Phys. Chem. Earth, 31(4-9), 143-153, 2006.

Pulinets, S.A., Bondur, V.G., Tsidilina, M.N. and Gaponova, M.V.: Verification of the concept of seismo-ionospheric relations under quiet heliogeomagnetic conditions, using the Wenchuan (China) earthquake of May 12, 2008, as an example, Geomagn. Aeronomy, 50(2), 231-242, 2010.

Pulinets, S. and Ouzounov, D.: Lithosphere-Atmosphere-lonosphere Coupling (LAIC) model - an unified concept for earthquake precursors validation, J. Asian Earth Sci., 41(4-5), 371-382, 2011.

Pulinets, S.: Low-latitude atmosphere-ionosphere effects initiated by strong earthquakes preparation process, International Journal of Geophysics, Volume 2012, Article ID 131842, 14 pages, doi:10.1155/2012/131842, 2012.

Pulinets, S., and Davidenko, D.: Ionospheric precursors of earthquakes and global electric circuit, Adv. Space Res., 53(5), 709-723, 2014.

Pulinets, S. A., Ouzounov, D. P., Karelin, A. V., and Davidenko, D. V.,: Physical bases of the generation of short-term earthquake precursors: A complex model of ionization-induced geophysical processes in the lithosphere-atmosphere-ionosphere-magnetosphere system, Geomagn. Aeronomy, 55(4), 521- 538, 2015.

Qin, K., Wu, L.X., Zheng, S., Bai, Y., and Lv, X.: Is there an abnormal enhancement of atmospheric aerosol before the 2008 Wenchuan earthquake? Adv. Space Res., 54(6), 1029-1034, 2014.

Ryu, K., Lee, E., Chae, J.S., Parrot, M., and Oyama, K.-I.: Multisatellite observations of an intensified equatorial ionization anomaly in relation to the northern Sumatra earthquake of March 2005, J. Geophys. Res. Space Physics, 119, doi:10.1002/2013JA019685,2014a.

Ryu, K., Parrot, M., Kim, S.G., Jeong, K.S., Chae, J.S., Pulinets, S., and Oyama, K.-I.: Suspected seismoionospheric coupling observed by satellite measurements and GPS TEC related to the M7.9 Wenchuan earthquake of 12 May 2008, J. Geophys. Res. Space Physics, 119, doi:10.1002/2014JA020613, 2014b

Singh, R.P., Mehdi, W., Gautam, R., Kumar, J.S., Zlotnicki, J. and Kafatos, M.: Precursory signals using satellite and ground data associated with the Wenchuan Earthquake of 12 May 2008, Int. J. Remote Sens., 31(13), 3341-3354, 2010.

Sorokin, V. M., and Ruzhin, Yu.Ya.: Electrodynamic model of atmospheric and ionospheric processes on the eve of an earthquake, Geomagn. Aeronomy, 55(5), 26-642, doi:10.1134/S0016793215050163, 2015.

Surkov, V. V.: Pre-seismic variations of atmospheric radon activity as a possible reason for abnormal atmospheric effects, Ann. Geophysics, 58(5), A0554, 2015. 
Nat. Hazards Earth Syst. Sci. Discuss., doi:10.5194/nhess-2016-172, 2016

Manuscript under review for journal Nat. Hazards Earth Syst. Sci.

Published: 23 June 2016

(c) Author(s) 2016. CC-BY 3.0 License.

Tramutoli, V., Di Bello, G., Pergola, N., and Piscitelli, S.: Robust Satellite Techniques for remote sensing of seismically active area, Ann. Geophysics, 44, 295- 312,2001.

Tramutoli, V., Cuomo V., Filizzola C., Pergola N., and Pietrapertosa, C.: Assessing the potential of thermal infrared satellite surveys for monitoring seismically active areas. The case of Kocaeli (İzmit) earthquake, August 17th, 1999, Remote Sens. Environ., 96, 409-426, 2005.

Tramutoli, V., Aliano, C., Corrado, R., Filizzola, C., Genzano, N., Lisi, M., Martinelli, G., and Pergola, N.: On the possible origin of Thermal Infrared Radiation (TIR) anomalies in earthquake-prone areas observed using Robust Satellite Techniques (RST), Chem. Geol.,339, 157- 168, 2013.

Tramutoli, V., Corrado, R., Filizzola, C., Genzano, N., Lisi, M. and Pergola, N.: From visual comparison to Robust Satellite Techniques: 30 years of thermal infrared satellite data analyses for the study of earthquake preparation phases, Boll. Geof. Teor. Appl., 56, 167-202, 2015.

Walker, S. N., Kadirkamanathan, V., and Pokhotelov, O. A.: Changes in the ultra-low frequency wave field during the precursor phase to the Sichuan earthquake: DEMETER observations, Ann. Geophys., 31, 1597-1603, doi:10.5194/angeo-31-1597-2013, 2013.

Xiong, P., Shen, X. H., Bi, Y. X., Kang, C. L., Chen, L. Z., Jing, F., and Chen, Y.: Study of outgoing long wave radiation anomalies associated with Haiti earthquake, Nat. Hazards Earth Syst. Sci., 10, 2169- 2178, 2010.

$\mathrm{Xu}, \mathrm{T} ., \mathrm{Hu}, \mathrm{Y} ., \mathrm{Wu}$, J., Wu, Z., Li, C., Xu, Z., and Suo, Y.: Anomalous enhancement of electric field derived from ionosonde data before the great Wenchuan earthquake, Adv. Space Res., 47(6), 1001- 1005, 2011.

Yan X., Shan X., Zhang X., Qu C., Tang J., Wang F., and Wen, S.: Multiparameter seismoionospheric anomaly observation before the 2008 Wenchuan, China, Mw7.9 earthquake, J. Appl. Remote Sens. 7(1), 073532, doi: 10.1117/1.JRS.7.0773532, 2013.

Zeng Z. C., Zhang B., Fang G. Y., Wang D. F. and Yin H. J.: An analysis of ionospheric variations before the Wenchuan earthquake with DEMETER data, Chinese J. Geophys., 52(1), 13-22, 2009.

Zhao, B., Wang, M., Yu, T., Xu, G., Wan, W., and Liu, L.: Ionospheric total electron content variations prior to the 2008 Wenchuan Earthquake, Int. J. Remote Sens., 31(13), 3545-3557, 2010.

Zhao, B., Wang, M., Yu, T., Wan, W., Lei, J., Liu, L., and Ning, B.: Is an unusual large enhancement of ionospheric electron density linked with the 2008 great Wenchuan earthquake?, J. Geophys. Res., 113, A11304, doi:10.1029/2008JA013613, 2008.

Zhang, X. and Shen, X.: Electromagnetic Anomalies around the Wenchuan Earthquake and Their Relationship with Earthquake Preparation, International Journal of Geophysics, Volume 2011, Article ID 904132, 8 pages, doi:10.1155/2011/904132,2011.

Zhang, X., Shen, X. and Miao, Y.: Electromagnetic anomalies around Wenchuan earthquake and 
Nat. Hazards Earth Syst. Sci. Discuss., doi:10.5194/nhess-2016-172, 2016

Manuscript under review for journal Nat. Hazards Earth Syst. Sci.

Published: 23 June 2016

(c) Author(s) 2016. CC-BY 3.0 License.

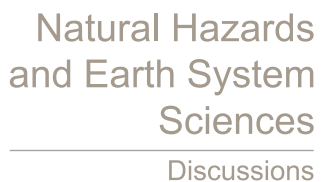

(c) (i)

Discussions

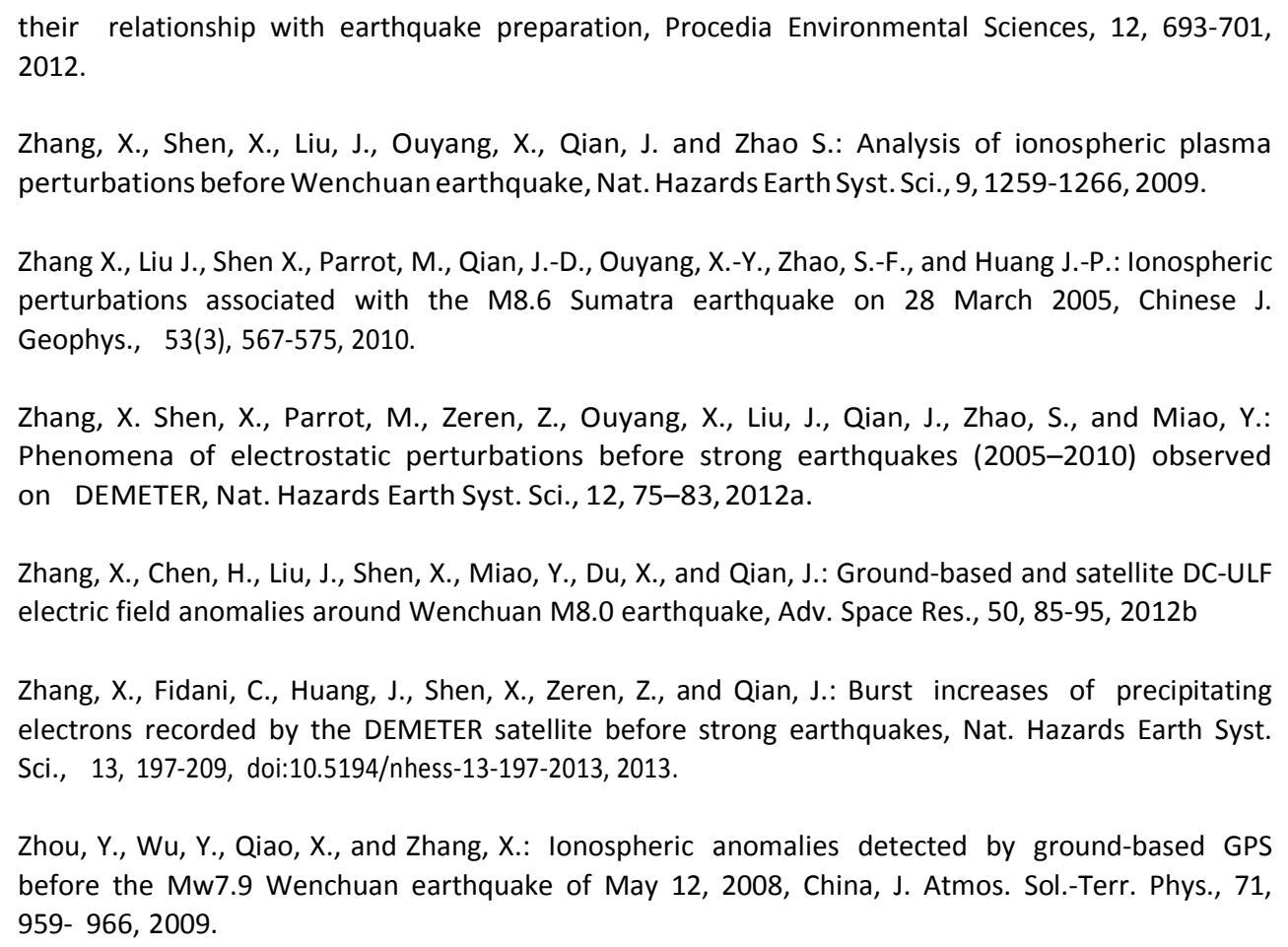

